\author{
Patryk Skupniewicz \\ https://doi.org/10.26485/AAL/2020/66/6
}

\title{
SCENE OF FIGHTING TIGERS ON A SASANIAN PLATE FROM MES 'AYNAK. NOTES ON THE COMPOSITION
}

\begin{abstract}
The article discusses, from formal perspective, the mounted hunting scene on the Kushano-Sasanian silver plate found in Mes Aynak in Afghanistan. The scene represents the model related to other Sasanian silverware, however with significant variances. When compared the scene to other models defined by Author, conclusion is made that except for several "canonical" layouts, Sasanian toreuts, allowed themselves a dose of freedom in combining them. This phenomenon seems to be related to peripheries of the Sasanian Empire and model of a sword-wielding rider in combat with large felines while holding an object in outstretched left hand was defined as originating from Kushanshahr and combining Assyrian and Achaemenid formulae of men killing beasts with mounted archer/lancer layouts popular in Sasanian silver.
\end{abstract}

Key words: Kushano-Sasanian art., silver plates, iconography

\section{SCENA WALKI Z TYGRYSAMI NA SASANIDZKIEJ PATERZE Z MES 'AYNAK. UWAGI NA TEMAT KOMPOZYCJI}

\begin{abstract}
ABSTRAKT W prezentowanym studium poddano ocenie, $\mathrm{z}$ formalnego punktu widzenia, scenę konnego polowania z kuszano-sasanidzkiej partery znalezionej w Mes Aynak, w Afganistanie. Scena reprezentuje model pokrewny dziełom znanym z toreutyki sasanidzkiej, jednakże z wyraźnymi różnicami. Porównując scenę z modelami wyróżnionymi przez Autora, pojawił się wniosek, że sasanidzcy mistrzowie obróbki srebra, poza „kanonicznymi” figurami, pozwalali sobie na formalne eksperymenty. Jest to zjawisko znane z peryferii imperium Sasanidów, a model obejmujący jeźdźca uderzającego mieczem „,kotowatego drapieżnika” a w wolnej, wyciągniętej ręce trzymającego inny obiekt, wykształcił się w Kuszanszahr i łączy w sobie asyryjskie i achemenidzkie formuły ludzi zabijających dzikie bestie z układami ukazującymi konnego łucznika czy jeźdźca operującego włócznią, znane z sasanidzkigo srebra.
\end{abstract}

Słowa kluczowe: sztuka kuszano-sasanidzka, srebrne patery, ikonografia

Introduction

The silver, partially gilded, plate found by the Czech expedition at the Mes 'Aynak site in northern Afghanistan (FIG.1), with the scene of a fight between a heroic rider and tigers, is an extremely important contribution to the development of knowledge about Sasanic aesthetics. ${ }^{1}$ The very fact of the appearance of a new vessel, of a certain provenance, must cause a kind of excitement among researchers of Sasanian toreutics and, more broadly, among researchers of post-Last Sasanian Iran and Central Asia. The Mes 'Aynak plate stands out, in its composition details, from the recognised body of silver vessels decorated with scenes of the so-called

Mleziva 2016: 99-105; Skupniewicz 2019: 76. "royal" or "princely" hunting. The very term of the theme, used in the usual way, should be rewritten, because we should speak, rather, of two types of hunting depicted in the art of Sasanian Iran: (1) scenes of heroic struggle against beasts, where the main character, most often bearing royal attributes, stumbles upon one or two life-threatening animals or symbols of unbridled, natural power; this type of representation emphasises the heroic dimension of the character; the second type (2) are representations of the pursuit and killing of animals that do not threaten the main character and flee in large numbers, which, most likely, should be interpreted as a visualisation of opulence, associated with royal hunting in paradeisos. ${ }^{2}$ The discussed 
plate from Mes 'Aynak belongs to the first group, although, as mentioned above, it differs from the known representations of this type, making important contributions to the knowledge of the principles governing the Sasanian aesthetics. The hunting scenes emphasising the opulence of prey rather than heroism of the personage will be excluded from the further analyse.

The aim of this article is to place the scene among the defined compositional schemes of scenes of fighting with beasts in the art of Sasanian Iran and regions culturally related to it, indicating how the scene from the plate from Mes 'Aynak combines the well known principles of composition with the elements, so far unknown. The unorthodox character of the scene from Mes 'Aynak' ${ }^{\text {' }}$ does not deny the fundamental schematic character of the Sasanian toreutic decoration, however, it draws attention to a certain freedom in the application of the composition principles, and therefore suggests the relative lack connection between them and the program imposed by the authority of royal power ${ }^{4}$. It seems, therefore, that the repeated principles of patterns and composition resulted from the aesthetic conservatism of the recipients ordering dishes, and thus, from the methods of training craftsmen, and not from centrally controlled ideological norms. It can be argued that it was the demand for luxury goods that determined the principles of decorating the vessels, and the relative reduction in the number of available forms results from the taste of the upper social strata of Iran, attached to the stability of traditional decorative formulas. Survival of the formulas after the fall of the Sasanian state, and their popularity outside the empire is another argument against the idea of centralised, censored, strictly state-controlled aesthetics ${ }^{5}$. This, in turn, indicates a different function of images, not necessarily related to the ideology of royal power. Taking into account the

3 Skupniewicz 2019: 76.

4 Skupniewicz 2009: 49-50; Skupniewicz 2015: 186-188.

Discussion: Gray 1991; Skupniewicz 2009, 4950; Preiser-Kapeller 2019; Bollok 2015 - the latter Author illustrates and proves with clarity that the motifs attributed as Sasanian cannot refer just to territory of late pre-Islamic Iran but their wandering nature allows only approximations. Recent studies of Compareti 2019 illustrate that even in the later period, Sasanian art adopted the foreign elements and not solely Roman-Byzantine elements. On the adoption of Western motifs: Ettinghausen 1972, Mackintosh 1978. Soudavar 2003, 41 advocating alleged "propagandistic" nature of Sasanian art, including toreutics. fact that the scene from the plate from Mes 'Aynak enriches the previously known visual structures with new elements, it should be noted that the idea proposed by me earlier, that the interweaving and binding of schemes was a feature allowing for late dating of the object, should be revised.

Incidentally, there will be a note about the iconographic function of the sword in the Sasanian iconography of the fight against beasts and a specific revolution in this respect caused by the aesthetics of the Sasanian Iran.

\section{Description of a Monument (Fig. 1)}

A scene placed in a circular, compact format. A rider shown on a disproportionately small horse galloping to the left, depicted in a "flying gallop". To the right of the rider, a male and female tigers are shown. They are positioned slightly diagonally, almost vertically, with their paws stretched out towards the rider. The rider's head is shown in the profile, shoulder and body in frontal view, the leg in profile, slightly bent back, the foot is stretched down. A sheath of a sword hangs from the belt. The rider's right arm, rigidly drawn diagonally, crosses the upper part of the man's torso, a sword in his hand with a horizontally depicted blade inserted into the tiger's breast. The rider's left arm is raised vertically, holding a tiger cub in his hand, lying with its belly upwards. Another tiger is shown stretched and under the horse. Below were placed three conventionally depicted mountains. The vertical axis of the picture is marked by the line of the rider's arm, his hips, foot and shoulder of the lying tiger. The horizontal axis is marked by the back of the horse and is emphasised by a visible fragment of the sword's blade.

The man's face is long and slender with a prominent nose and a large, wide open eye. The man is bearded and has a wavy moustache. The head is covered with an oval headgear, covered with a pattern of dots and a vertical line, topped with a crescent, whose fastening is hidden behind a bow of the top diadem. Three triangular ends of the ribbons protrude horizontally and rigidly from behind the knot. Dense curls fall on the neck, from behind them two ribbons of a diadem wave vigorously.

The body, arms and legs of the man are covered with dense wavy lines of cloak folds. On his shoulders, he has rounded hems. Two ribbons blow to the left from behind her back. A narrow belt on the hips, fastened with two round buckles with a bow and ribbons. The scabbard belt of the sword supports the lower parts of the tunic on the thigh and saddle. 
Trousers or man's leggings pulled down with ribbons and round buckles at the height of ankles. The ribbons blow to the right behind the foot.

The horse is muscular, heavily built with schematically marked muscles and joints. The neck is bent round, the head is turned back towards the breast. Mane cut, slightly longer over the head. Above the forehead, the top is bound with a ribbon. The reigns are decorated with a dense row of triangular elements. Similarly decorated is the rumpstrap. There is a decorative necklace on the horse's neck. The elements of the saddle cannot be seen, covered by the leg of the rider and his tunic, the saddle cloth is decorated with a zigzag pattern, two ribbons blow from the edge.

The bodies and heads of tigers are stylised, covered with rows of dots and stylised fur tufts.

\section{The Scene in the Context of Combat Patterns in the Sasanian Aesthetics}

The repetitiveness of motifs and schemes in Sasanian small art allows for the analysis, by means of these repetitive elements or morphems, which can be divided into structural or compositional ones, including fixed structures or compositional formulas, and detailed ones, such as methods of showing the animals or figures, positions given to characters due to the weaponry used, armament or objects placed in the scenes, which I will call props ${ }^{6}$. Props in this sense refer more to narrative systems, "rhetorical", of supposed meaning, perhaps referring the scene to the not preserved stories.

\section{II.1. Composition Formulas}

The composition of the scene of the fight with beasts from the Mes 'Aynak' plate does not belong to any of the classical visual formulas used in the decorations of Sasanian silver that I have identified elsewhere but for sake of clarity of discussion I will

6 I used the same methodology in: Skupniewicz 2018A, Skupniewicz 2018B; also see: Ciafaloni, Della Roca De Candal 2011 and Thompson 2008. The excellent, latter work was an immediate methodological inspiration in observing continuous flow of compositional principles in Iranian art. Thompson's method was adopted to the heroic mooted combat depictions but due to their usually compact format, the method, made for examination large scale royal reliefs, was simplified but other aspects were developed. Another work to which I owe credit in building this method is Pirson 2014. present their scrutinised version below ${ }^{7}$. The four most common formulas, therefore, considered to be the most characteristic of Sasanian art, are the variants of composition with a heroic "hunter" confronted with one beast placed vertically and the other stretched under the hooves of his mount (in rare cases the horizontal beast is omitted). Depending on the directions of the movement of visual masses, the following formulas can be distinguished, whose conventional names refer to the default, narrative situation of the hero's horse. Similar arrangements showing pedestrian struggles must be treated differently due to differences in composition principles. Naturally, these situations are neither an indication of a real or realistic situation in the spatial sense, nor a direct reference to a narration, as the schemes may be utilised to number of heroic stories. Sasanian art is conventional in nature, so it is not to be assumed that the rulers hunted in crowns and the four-legged stood vertically on their hind legs. The discussed formulas describe the structure of Arnheim's visual masses $^{8}$.

- Confrontation, when the rider, the direction of his attack and the vertical beast are directed towards the center of the pictorial field, heading decisively towards each other, creates the impression of a vigorous confrontation.

\section{EXAMPLES:}

- Plate from Anikovska, in Pushkin Museum, Tcherdyne. ${ }^{9}$ (Fig. 2)

- $\quad$ Seal from Brussels, Musèes Royaux, 657. ${ }^{10}$

- Parthian seals from Old Nisa. They reveal the origin of the model, just like their predecessors showing the riders charging standing human opponent. ${ }^{11}$

- "Odaenathus Mosaic" from Palmyra. Although not representing directly the Sasanian iconography, the piece clearly follows the principle adopted by the Sasanian art.

- $\quad$ Sari stone disc. (Fig. 17)

- Chase, when the direction of the rider's movement and attack is identical to that of the vertical beast, so that the victim seems to be escaping from the attack.

7 Skupniewicz 2015; Skupniewicz 2019.

Arnheim 1978: 24-53.

9 Harper, Meyers 1981: 70-72, 222, P1. 21, relation to earlier battle or man versus man combat scenes: Skupniewicz 2019B: 324-326.

10 Ritter 2010: 293, Taf. XVIII.

11 Gaibov, Košelenko 2008. 


\section{EXAMPLES:}

- $\quad$ Freer Gallery of Art plate, 34.23.12 (Fig. 3)

- Arthur Sackler Gallery plate, S1987.109. ${ }^{13}$ (Fig. 4)

- Plate from Chilek. ${ }^{14}$ (Fig. 5)

- Plate from Kutais in Hermitage, S 58. ${ }^{15}$ (Fig.6)

- $\quad$ Plate from Nizhne Shakhrovka. ${ }^{16}$ (Fig.7)

- Post-Sasanian plate from Hermitage, S-13. ${ }^{17}$ (Fig. 8)

- Escape, when the rider's movement is directed beyond the image field, while the beast and the hero's attack directs towards the center, creating the impression that the rider is escaping the animal chasing him.

\section{EXAMPLES:}

- Cleveland Museum of Art plate, 62.150.18 (Fig. 9)

- $\quad$ Hermitage plate with Shapur, S-253. ${ }^{19}$ (Fig. 10)

- Pur-e Vahman plate in Hermitage, S-247. ${ }^{20}$ (Fig.11)

- Bowl identified as Hephtalite from British Museum, OA 1963-12-10.1. ${ }^{21}$ (Fig.12)

- Reversed, i.e right and left sides switched: Shemakha plate. ${ }^{22}$ (Fig. 13)

- Kushano-Sasanian plate from private, Japanese collection. ${ }^{23}$ (Fig.14)

- Double Escape. The hero's horse and beast move towards the edge of the image field and his attack towards the center, so the hero escapes from the beast that runs away from him.

12 Harper, Meyers 1981: 61-64, 216, Pl. 15; Gunter Jett 1992: 106-113.

13 Gunter, Jett 1992: 118-120.

14 Harper, Meyers 1981: 83-85, 231, Pl. 30; Maršak, Kikiris 1969.

15 Harper, Meyers 1981: 85-86, 232, Pl. 31; Trever, Lukonin 1987: 110.

16 Harper, Meyers 1981: 86-87, 233, Pl. 32; Trever, Lukonin 1987: 108.

17 Trever, Lukonin 1987: 109-110; Harper, Meyers 1981: 140-142.

18 Harper, Meyers 1981: 215, 60-61, Pl. 14; Harper 1978: 38-39.

19 Trever, Lukonin 1987: 107.

20 Trever, Lukonin 1987: 112.

${ }^{21}$ Harper, Meyers 1981: 130-131; Skupniewicz 2009: 58-59.

22 Harper, Meyers 1981: 48-50, 209, Pl. 8.

23 Tanabe 2001.

\section{EXAMPLES:}

- Krasnaya Polyana plate in Abkhazian State Museum, 47-71. ${ }^{24}$ (Fig.15)

- Sari plate in Iran Bastan Museum, 1275.25 (Fig. 16)

The remaining, below listed, visual formulas, repeatedly employed in the Sasanian silver, do not constitute a development of the basic model with the animal vertically positioned as the hero's opponent:

- $\quad$ Thrusting a spear / throwing a javelin down diagonally. The rider strikes with his two-handed spear diagonally downwards, forward, or throws the javelin in that direction, aiming at the beast placed either horizontally or along the edge of the vessel. In principle, the described composition schemes do not depend on the weapon used, which qualifies for the next set of non-compositional analytical elements, i.e. props, but the use of a shafted weapon in the diagonal direction of attack radically changes the composition and the dynamics of the pictorial field which change from strictly horizontal or vertical elements to a combination of horizontal and diagonal movements.

EXAMPLES:

- Saksankhur clasp. ${ }^{26}$

- Synya family plate. ${ }^{27}$ (Fig. 18)

- Burnes plate - now lost, known from the drawings. ${ }^{28}$

- Bowl identified as Hephtalite from British Museum, OA 1963-12-10.1. ${ }^{29}$ (Fig. 19)

- Stucco fragments from Chal Tarkhan. ${ }^{30}$ (Fig. 20)

- Backwards thrust is depicted on the vase from Yuldus. ${ }^{31}$ (Fig. 21)

- Backwards thrust on the seal from Louvre, AO 2216.32

24 Harper, Meyers 1981: 50-52, 210, Pl. 9.

25 Harper, Meyers 1981: 52-55, 211, Pl. 10; Harper 1978: 33-34.

26 Marshak 2002: 9, fig. 10; Skupniewicz 2009: 58-59.

27 Baulo 2002; Skupniewicz 2009: 62-63.

28 Harper, Meyers 1981: 55-56, 212, Pl. 11a-b.

29 Harper, Meyers 1981: 130-131; Skupniewicz 2009: 58-59.

30 Skupniewicz 2009: 59-60.

31 Šlyahova 1977: 289-291; Skupniewicz 2009:

60-61; Harper 2006: 128, 150, Fig. 71.

32 Ritter 2008: 189-199, 293, Tab. XVIII. 
- The hunter is attacked by two beasts diagonally from below. Two beasts throw themselves at the hero from the bottom right of the pictorial field diagonally upwards. What is important for further consideration is that the formula only includes heroes armed with swords.

EXAMPLES:

- "Kushanshah Bahram" plate from Hermitage, S24. ${ }^{33}$ (Fig. 22)

- Two, almost identical, plates with a king combating the tigers from British Museum (124092) and Hermitage. ${ }^{34}$ The latter being suspected to be a forgery, however the arguments against it do not seem convincing. Re-examination of both pieces might provide more decisive results. (Fig. 23)

- Escape-confrontation. The formula is represented by a single plate from Fabricius collection, ${ }^{35}$ (Fig. 24) where the rider is confronted with an attacking bull, shown as a protome, but the protagonist's horse turns his head away. There is also no victim stretched under the hooves of the mount. It seems that this is a local, eastern variant of the confrontation formula, in which the vertical stretch of the beast has been replaced by the showing of the front part, and the horse reversing the head is an element of the local post-hellenistic heritage.

- Animals shown realistically, i.e. horizontally. This is a rare formula in the Sasanian iconography of scenes of fighting with beasts, which preferred to stretch the beast vertically and/or horizontally, or shorten it to a protome. It appears in the hunting scenes, but in the case of the Copenhagen vessel, we are dealing with a scene in which the rider shoots a single goat, which does not correspond in any way with the scenes of "hunting", whose characteristic feature is the multitude of species and abundance of animals. Showing the pursuit of a single victim gives the scene, in the formal layer, heroic features. Nevertheless, showing the whole animal horizontally, without reduction to the front part, or showing it in a diagonal jump, is an exemption from the principles of constructing scenes of heroic struggle with animals. The

33 Harper, Meyers 1981: 72-74, 224, Pl. 23; Trever, Lukonin 1987: 108.

34 Harper, Meyers 1981: 76-77, 226, P1. 25.

35 Harper, Meyers 1981: 77-79, 227, Pl. 26; Harper 1978: 58-59. general rarity of the most natural display model indicates that the visual language of the Sasanian iconography referred, in terms of composition, to the inherited patterns, not to the observation of life.

EXAMPLES:

- David Collection bowl from /Copenhagen, 2/1984. ${ }^{36}$

- $\quad$ Late Parthian graffiti from Hatra. ${ }^{37}$ (Fig. 25)

- $\quad$ The hunter kills the animal he mounts. This is a unique formula represented by a plate from the British Museum (124091), ${ }^{38}$ perhaps also one of the stuccos from Chal Tarkhan, where the act of killing a deer itself is not clearly emphasized, the rider rides an animal holding its antlers. ${ }^{39}$

- Mixed. Some of the representations include features belonging to several separate formulas, showing several animals, which brings them closer to the scenes of "hunting", but different species, life-threatening, which makes them an element of the genre of fighting with beasts. Similarly, beasts are most often shown in accordance with the above formulas.

EXAMPLES:

- Plate from Museum fur Islamische Kunst, Berlin, I.4925. ${ }^{40}$ (Fig. 26)

- $\quad$ Bastis collection plate. ${ }^{41}$ (Fig. 27)

- Sogdian imitation of Sasanian plate with the lion-hunt. ${ }^{42}$ (Fig. 28)

The formulas for depicting fighting with beasts on foot must be treated separately. Despite the thematic relation of some of them to the above compositional principles, they differ significantly in form and cannot be treated as their subtypes. Although the patera of Mes 'Aynak includes a horse show, the presentation of pedestrian formulas will be used in later deliberations.

- Chase on foot. The central character of the hero directs his attack to the right, towards the ani-

36 Harper 2006: 146, Fig. 66.

37 Harper 2006: 79; Skupniewicz 2009: 60-61.

38 Harper, Meyers 1981: 57-60, 214, P1. 13; Harper 1978: 34-35.

39 Harper 1978: 116.

40 Harper, Meyers 1981: 68-70, 221, P1. 20; Skupniewicz 2009: 56-57.

41 Grabar 1967: 50-52, 94, Pl. 4; Skupniewicz 2009: 61-62.

42 Maršak 1971: 120; Skupniewicz 2009: 59-60. 
mal directed outside the image field. The dead animal is not placed under the feet of the ruler.

\section{EXAMPLES:}

- Plate with Yazdegird I killing a deer, Metropolitan Museum of Art, 1970.6. ${ }^{43}$ (Fig. 29)

- Klimova plate from the Hermitage with a hero killing a leopard with a sword, S42. ${ }^{44}$ (Fig. 30)

- Nizhni Novogrod plate, where the king uses a lasso, also in Hermitage. ${ }^{45}$

- Confrontation on foot. Again, this motif seems to be seemingly similar to horse formulas, but by placing a large human figure it highlights the vertical character of the stage. The formula includes images of heroes armed with swords and spears

EXAMPLES:

- $\quad$ The side of a vase from the Hermitage. ${ }^{46}$

- Plate from the Arthur Sackler Gallery. ${ }^{47}$

- $\quad$ Plate from Shogakukan collection. ${ }^{48}$ (Fig. 31)

- Side decoration of the vase from Hermitage S-60.49

- Depictions on sigillography. ${ }^{50}$

- The hero with a bent knee fights the boars in the reeds. It is a characteristic model represented by two plates from the Shelby and White Collection $^{51}$ and a tomb from Feng Hetu ${ }^{52}$. It depicts the main character with a spear at hip level, directed from the attacking wild boar to the right, his right leg bent in the knee and holding back the charging wild boar to the left.

\section{EXAMPLES:}

- Shelby and White Collection plate. (Fig. 32)

- $\quad$ Plate from the Tomb of Feng Hetu. (Fig. 33)

43 Harper, Meyers 1981: 63-64, 217 Pl. 16; Skupniewicz 2009: 51-52.

44 Harper, Meyers 1981: 74-76, 225, Pl. 24; Trever, Lukonin 1987: 107-18.

45 Harper, Meyers, 1981: 82-83, 230, Pl. 29; Trever, Lukonin 1987: 108.

46 Trever, Lukonin, 1987: 115; Skupniewicz 2009: 52-55.

47 Gunter, Jett 1992: 177-179.

48 Tanabe 2001: 178-180; Skupniewicz 2009: 51-52.

49 Trever, Lukonin 1987: 115-116, Pl. 86.

50 Ritter 2010: 90-98,Taf. X; Skupniewicz 2009: 52-53.

51 Harper 2006: 123-125, 148, Pl. 68-69; Skupniewicz 2009: 50-51.

52 Harper 2006: 123-125, 148, Pl. 68-69: Skupniewicz 2009: 50-51.
- $\quad$ The hunter is attacked by two beasts diagonally from below. The only representation of this formula applied to foot combat does not come from toreutics but from the rock relief from Sar Mashhad where the scene with the king killing lions with the sword. The beasts spring out to the king who stands on both feet and wields the sword with one hand while holds the female figure behind him with the other.

Most of the above formulas stem Hellenistic legacy, although they often refer to the Achaemenid tradition, which draws on selected elements of Assyrian aesthetics. ${ }^{53}$ Identical compositional schemes were originally created to show the fight between warriors and were transferred to the scenes of fighting with beasts already in the Achaemenid period, but it was the Sasanian art that began to use these concise, compact compositions exclusively for the scenes of fighting with beasts. The Sasanian scenes of fighting between people, even if they maintain a similar arrangement of movement directions and constant elements, are horizontally stretched, distributed in a different format, which completely changes the relations of Arnheim's visual masses. The only Sasanian formulas that cannot be recognised as originating from previous models of depicting human combat are: The hunter kills his the animal he mounts, Mixed and The hero with his bent knee fights the boars in the reeds.

Taking into account the above observations, the Mes 'Aynak plate (Fig. 1) does not correspond directly any of the above mentioned models of horseback fighting with beasts. It combines elements of the Escape scheme (the rider moving away from the beast, directed towards him, standing on the back legs), but the number of attacking beasts has been doubled, and the tigers themselves are shown slightly oblique, which would connect the scene with the model Hunter attacked by two beasts diagonally from below. However, the beasts do not attack from below, and the third dead tiger is stretched under the horse. The appearance of three beasts would connect the scene with the Mixed model, but only one species of beast is shown, and the arrangement is not a simple tracing paper of several models overlapping each other, but rather a scheme of Escape with two persecutors, shown obliquely, allowing them both to be placed in a round plate format. A similar arrangement can be found on a small stone relief found near Taq-e Bostan ${ }^{54}$ (Fig. 34). The relief scene

\footnotetext{
53 Skupniewicz 2018A; Skupniewicz 2018B.

54 Moradi, Compareti 2019.
} 
depicts a struggle between people and belongs to the model of a Spear thrust / javelin throw diagonally down, but under the horse's hooves two, stretched victims are shown. Similar doubling of victims can be observed on the Mes 'Aynak plate (Fig. 1), although in this case they are standing prey, but taking into account the Escape model, the vertically shown beasts are the target of the rider's attack, while in the case of spear thrust/ javelin throw diagonally downwards the target of the attack is usually under the rider, in the standard examples of this model, The diagonal accent determined by the direction of the impact is not weakened by the addition of a vertical element, characteristic of the first four compositional schemes, which makes the cited relief a combination of spear thrust/throw of the javelin down diagonally and the Confrontation, although the element of the proper confrontation disappears by directing the attack downwards. The Sogdian plate with the depiction of stylised Sasanian prince or king killing lions with the lance (Fig. 28), also combines the Confrontation formula with Downwards Thrust, however the victims are not doubled and the direction of the thrust was changed to more horizontal, in order to compromise both motifs. It seems that combining known formulas has become a relatively accepted practice in Sasanian art, especially on the outskirts of the Sasanian empire in the late period.

\section{II.2. Lesser Conventions}

The Mes 'Aynak plate shows a rider in combat with the beasts, sword in hand. Although the sword is not a weapon specifically suited for fighting animals, especially from horseback, it is depicted being wielded in several works of Sasanian art. Naturally, as could be expected, the scenes of hunting and beast combat are more frequently showing protagonists using the bows and the shafted weapons which must have been actually more common on the hunting grounds, given their reach. Sasanian iconography provides examples of the lariats being used against life threatening animals, however they are even more seldom than swords. It should be also highlighted here again hat the majority of the compositional formulae of the Sasanian iconography of heroes fighting the beasts derive from the conventions transmitted through Hellenistic art and rooted in Achaemenid and Assyrian traditions where, ${ }^{55}$ the same visual conventions were mainly employed to depict the combat between humans. The transfer

55 Skupniewicz 2018A; Skupniewicz 2018B. from battle scenes to heroic hunt did not affect the combative nature of the depictions and could be easily reversed, as can be exampled by the quoted stone relief from Taq-e Bostan, however the survival of the connection of the basic Chase formula in battle context is attested by Byzantine or Longobard silver plate from Isola Rizza. ${ }^{56}$ The dominant weapon of the battle formulae, the icons of violence, of the Hellenistic art are lances and spears, which is in line of the military practice of the era. Swords in hands of the cavalrymen are extremely seldom in antiquity as they were the riders' weapons of the last resort and therefore emphasised rather dire straits of the warrior than his heroic victory. ${ }^{57}$ Swords are more likely being shown used against the riders by the defeated infantrymen or in combat between the mounted warriors. The shafted weapons were the primary weapons of the cavalry unless they were mounted archers. The bow was devastating horsemen weapon and in Sasanian iconography of heroic combat with the beasts it successfully surpassed lances and javelins. The range of a lance or a hurled javelin allowed application of former formulae without radically compromising the proportions of the designs. The adoption and widespread of the long-bladed cavalry swords by the Parthians allowed further evolution of armes blanches in early Sasanian period and the swords must have lost their brand of "trooper's last resort". The swords were allowed to iconography and were fitted to existing formulae but the formula The hunter is attacked by two beasts diagonally from below was seemingly developed specifically to allow showing the rider using long bladed sword, which might suggest original association with the, otherwise not preserved, narrative or a topos, perhaps describing the hero's combat with the boars. The longevity of the motif supports this view. In Ilkhanid illustrations of Shahname, shows Bizhan in his combat with the boars of Imrān wielding a sword from horseback, reaching the beasts in somehow similar way as depicted on the Kushano-Sasanian plate from Hermitage with depiction of "kushanshah Bahram". ${ }^{58}$ The story itself does not provide any description of Bizhan's

56 Skupniewicz 2015: 189.

57 Naturally some crude depictions might leave the topic of illustrated weapon open to discussion however it is also known that the technique of hurling the javelins or darts held close to the head, was employed already in Achaemenid times. Without clear picture of the long-bladed sword, with all its elements, held behind rider's head, it is impossible to state with certainty what weapon was intentionally shown by the artisan.

58 Swietochowski, Carboni 1994: 76-77. 
feat, the illustration, thus, follows an existing visual tradition which, in turn, seemed to refer to earlier narrative. As no all illustrations of Bizhan's heroic deed showed him on horseback, ${ }^{59}$ it must be assumed that it was illustrator's decision to choose from available compositional formulas. It is also worth pointing that similar formula of swords used to kill beasts from horseback was applied to the art of Persian book illustrations and remained there, at least, until Safavids. It seems that once the motif of ailing the boars with the sword from horseback was adopted to the visual language of Sasanian art, it was transferred to depictions of the combat with other animals.

Sasanian depictions of the sword wielding heroic figures fighting the beasts whether on foot or mounted represent three general types:

- The hero with his left arm raised and right arm shown diagonally across the torso either thrusting or slashing the beast with the sword.

This is a predominant model of showing the protagonist in his combat with the beasts while using the sword. The shoulders are always shown frontally, thus emphasizing their breadth, extended left arm may either hold the victim, usually by ear, or may carry a bow or wild feline cub. The latter two varieties depict the left arm slightly raised, however the right arm is always extended straight diagonally across the chest and abdomen. The model is applied to both mounted and foot depictions however given the necessity to manipulate the proportions of the riders and horses, where the mounts are decreased in size to fit the large beasts, occasionally depicted stretched upright and lying below the horse (as in case of Kushano-Sasanian plate from Japanese collection and Mes 'Aynak plate), to the size of the main personage. It seems that the stylisation was adopted from the illustrations of fight on foot. There is a relation of the type with the body position of the royal and divine personages in Sasanian investiture scenes where similar treatment of frontally places shoulders and extended arms can be found, however the only analogy from the combat context comes from famous "Shapur cameo" (Fig. 35), however in these the swords of protagonists are shown sheathed. For obvious reasons all archers are shown with their left arms extended. Some resemblance may be found with late Parthian, early Sasanian depictions of the heroes strangling lions, however their arms are not extended in straight horizontal lines and swords remain in the scabbards.

59 Swietochowski, Carboni 1994: 100.
In these situations, it is the right hand which is active while the left-hand rests on the hilt or the belt. The most direct inspiration for the Sasanian model of the protagonist with an extended left arm, killing a beast with the sword, comes from Achaemenid iconography where the "royal guardsmen" are often shown holding the griffins and stabbing them with akinakai. The model itself was borrowed, and developed to Persian taste, from Assyrian royal hunt iconography, where the kings stab the lions while holding their thoroats in the firm grip of their left hands. ${ }^{60}$ It seems, therefore, that the model was created to show the victory over a beast of the personage on foot and was continued being used this way in Sasanian art (it can be encountered further in art of Panjikent where one of the wooden figures is shown in exactly the same way), however, when the swords lost their function of rider's weapons of despair and time came to adopt the sword wielding heroes to mounted combat with the beasts, this existing model was applied to settled compositional formulae. What is important to notice is that the Mes 'Aynak plate as well as plate from Japanese collection (Fig. 14), plate from British Museum depicting the king on the deer and the British Museum bowl identified as Hephtalite (Fig. 12), show the personages stabbing he beasts while the Hermitage plate with the boar hunt (Fig. 22) and the plates from British Museum and Hermitage with the scene of combat of the royal rider with lions (Fig. 23) show them clearly slashing through the flesh of the beasts. It is possible that the old formula (which was thrust-oriented - unsurprisingly given the slender shape and size of both Assyrian swords and Achaemenid akinakai), was rationalised to the most effective way of employment of long-bladed cavalry swords from horseback. The three mentioned plates may represent a separate sub-group of discussed convention, nevertheless the relation of the Hermitage (Fig. 22) and British Museum plates (Fig. 23) with Mes "Aynak (Fig. 1) and scene from the "Hephtalite" bowl from British Museum (Fig. 12), do not allow to define them as totally separate convention. The horse was reduced in size to allow this generally foot-model to be applied to cavalry compositional formula. Unrealistic and un-proportionally small horses are characteristic feature of Sasanian iconography however in case of Japanese collection plate the scale of the mount was reduced even further. The formula, which, it must be said, was playing

60 Ashurbanipal's reliefs from the North Palace in Nineveh, in British Museum, 1856.090948, see: Reade 2018: 52, 74 . 
with sizes from its early times which is evidenced by the depictions of the Achaemenid-Anatolian riders clashing oversized infantryman, just to match the principle of isokephalia. ${ }^{61}$ For similar, formal reason the model was adjusted to mounted scenes ignoring the realistic size relations. The axiom of extended left arm (not holding the beast throat or ear), which might be, at the time a kind of aesthetic principle of building a type of masculine silhouette, had to remain intact, so the artisans added an objecta row or a cub to visually justify the arm position. It is possible that a narrative inspired the depictions, including cub abduction, perhaps these unknown stories and songs inspired the sources of the "ethnographic" relations of using the cubs in lion and tiger hunts conveyed by the Roman literature. It seems clearly impossible that the young felines could be used as the baits to tempt their parents but kidnapping young predator from under parental protection must have been a remarkable feat. Reassuming, it seems most likely that the layout, once adopted from Achaemenid depictions of the "guardsmen" slaying the griffons (or directly from Assyrian images which, in Sasanian era, might not have been recognised as not belonging to Iranian heritage) and later "copied and pasted" on the format dominated by the depictions of the archers, which themselves derived from Hellenistic layouts rooted in earlier periods. The fact that the mounted bowman's left hand is outstretched towards the target made the transition of the motif easier which is clearly visible in case of Kushano-Sasanian plate from Japanese private collection.

EXAMPLES MOUNTED:

- The plates with tigers combat from British Museum (124092) and Hermitage. ${ }^{62}$ (Fig. 23)

- Kushano-Sasanian plate from private, Japanese collection. ${ }^{63}$ (Fig. 14)

- Bowl identified as Hephtalite from British Museum, OA 1963-12-10.1.64 (Fig. 12)

- $\quad$ Mes 'Aynak plate. (Fig. 1)

EXAMPLES ON FOOT:

- Klimova plate from the Hermitage with a hero killing a leopard with a sword, S42. ${ }^{65}$ (Fig. 29)

- Side decoration of the vase from Hermitage S-60. ${ }^{66}$

61 Boardman 2000: 152-178; Skupniewicz 2018A; Skupniewicz 2018B.

${ }_{62}$ Harper, Meyers 1981: 76-77, 226, Pl. 25.

63 Tanabe 2001.

${ }^{64}$ Harper, Meyers 1981: 130-131; Skupniewicz 2009: 58-59.

65 Harper, Meyers, 1981: 74-76, 225, Pl. 24; Trever, Lukonin 1987: 107-18.

${ }^{66}$ Trever, Lukonin 1987: 115-116, P1. 86.
- $\quad$ Plate from the Arthur Sackler Gallery. ${ }^{67}$

- Depictions on sigillography. ${ }^{68}$

- The hero holding his sword raised upwards, behind his torso.

This model comes from late and post-Sasanian examples, of which only one (Plate from Chilek Fig. 5) represents the basic formula involving one beast stretched vertically and the other one lying below the horse. Fabricius plate (Fig. 24) shows only a promote of a bull being fought by the rider and ignores the dead beast at the bottom. Similarly, the "Khorasan" style plate published by Maršak does not contain dead prey below mount's hooves however it is modelled after the confrontation formula with reversed sides (rider turned left). The Roman rider on "Shapur cameo" (Fig. 35) is also depicted with his sword held behind with the tip up. Later this sword position was adopted in monumental paintings of Panjikent however applied to depictions of the warriors on foot. It is difficult to find the origin of the model which might have been developed independently in Late Sasanian Iran as there are no seemingly direct influences, perhaps the Assyrian scenes of warriors wielding maces might be a sort of inspiration. Their adoption to the depictions of mounted swordsmen required evolution of the swords with the blades long enough to replace maces. It seems unlikely that the model was developed just through observation of nature as sword behind the body with tip up is probably the last position of the weapon which any rider would want. Functionally is does not allow any power to a cut or thrust, it might represent recovery after the cut (while the beasts ahead of the riders are not slain yet), alternatively, it could be made from attempts of depictions of the swords whirled overhead and gradually lowered behind the personage's torso. The visual advantage of the model is that it allows presenting entire sword being held by the rider, so it would acquire a quasi-insignial function.

EXAMPLES:

- $\quad$ Plate from Chilek. ${ }^{69}$ (Fig. 5)

- Plate from Fabricius collection. ${ }^{70}$ (Fig. 24)

- "Khorasan" style plate. ${ }^{71}$

67 Gunter, Jett 1992: 177-179.

68 Ritter 2010: 90-98,Taf. X; Skupniewicz 2009: 52-53.

69 Harper, Meyers 1981: 83-85, 231, P1. 30; Maršak, Kikiris 1969.

70 Harper, Meyers 1981: 77-79, 227, P1. 26; Harper 1978: 58-59.

71 Maršak 2017: 698, Drawing 251. 
- The hero holding the neck of his mount while slashing attacking beast.

This layout, full of dramatist, is represented by the single example of the Kushano-Sasanian plate from Hermitage (Fig. 22). This dramatic posture is unusual in Sasanian iconography, which depicts the winners in positions full of composure, calm in face of danger, somehow stiff, while the defeated, both human and animal, are energetic, dynamic, dramatic. Application of such a expressive posture might be an element of the Hellenistic tradition vivid in the eastern outskirts of the Iranian world, just like the turning head of the horse on the Fabricius plate. It should be added here that the plate from Japanese private collection attributed as Kushano-Sasanian does not add any dynamism to the scene which perfectly illustrates Sasanian "frozen dignity" of the victor.

\section{II.3. The Plate from Mes 'Aynak in Sasanian Aesthetic Principles}

In light of above observations, the plate from Mes 'Aynak does not strictly follow any of the patterns, usually originating from Hellenistic models, which are possible to extract from the corpus of Sasanian art known until now. In terms of composition it represents a new variant of the Mixed model, being a combination of Escape and The hunter is attacked by two beasts diagonally from below, however not following any of them as there are two beasts which does not happen in vast majority of Sasanian depictions of violence, with an exception of stone relief from Taq-e Bostan (Fig. 34) while the diagonally springing tigers do not attack the rider from below. The position of the body of the rider appears a derivation of an old motif of a heroic warrior stabbing a beast held with his left hand, adopted, already in Sasanian times to mounted depictions. The left arm of the rider is lifted up, raising a tiger cub, and not stretched horizontally. Given the relation with the plates depicting mounted "lion hunt" from British Museum and Hermitage (almost identical - Fig. 23) it is clear that the gradual raising of the arm appeared once the model was gaining independence from its old origins and at first the hand was not holding the victim's head which was replaced by other object, like a bow, as on the British Museum bowl and then, possibly a narrative of tiger hunt was added.

The discussed scene, not following slavishly, any of the defined models, sits well in general principles of the picture-construction in Sasanian art. The indirect relation with the compositional layouts and the conventions of representing the mounted swordsmen (stemmed from conventions of representing swordsmen on foot) places the depiction in the chain of development of Sasanian art and provides important information on its characteristic.

It is greatly unfortunate that modern view of the Sasanian visual culture relays, in general, on two groups of objects representing: on one hand, we have relatively well-dated rock reliefs and sculptural decorations of monumental architecture, on the other a group of objects of small-art, toreutics, decorated ceramics, fragments of textiles, which are impossible to date with any precision, difficult to attribute directly to any of the workshops and often disputed whether belonging to Sasanian or later periods. In fact, the latter group will include a number of objects which might be termed as "Sasanian visual heritage", as they heavily depend on the designs, layouts and motifs developed or merely popularised in Sasanian Iran, even if they were not made by the subjects of the shahanshahs. It is important to study these local varieties in order to improve the attribution tools however an aesthetic study has a comfort of staying focused on transformations of larger models and minor details in processual terms.

The headgear of the personage depicted on the Mes 'Aynak plate does not allow identification with any royal personage known from the coinage, but, as the matter of fact, this is the case of many, unless majority, of "royal" depictions in toreutics.

The fact that Mes "Aynak plate uses the common formulae of Sasanian art in rather unconstrained way, suggests that they resulted rather from the taste of the buyers and not from any official state-imposed program. Similarly the headgear of the heroes shown on the Sasanian silver, very rarely allows clear identification of the protagonist as a historical figure. If the silverware was produced on royal order or even under state control, with an idea of propagating of valiant deeds of a particular monarch, the ways of careful identification would be expected, which is not the case. In the past I suggested that the mixing of the existing formulae was typical for late or post-Sasanian period, my rationale at that time was that the layouts were gradually loosing their communicative value and that with passing time the original formats become less and less stiff. Perhaps the visual culture was "saturated" with the motifs and their combination was found more attractive but still sufficiently fulfilling the requirements of conservative taste and referring to the known compositions. This view of the evolution of the Sasanian compositional designs developing 
gradually from the depictions of the riders confronting the foot warriors or oversized animal promotes and finally vertically stretched quadrupeds to the most "classic" or princely-royal layout with the dead beast stretched under the horse, which in turn was later enriched by the minor formulae, proved incorrect in course of the further study. All layouts were developed before and were only re-applied by the Sasanian artisans. The Mes 'Aynak plate, of most likely Kushano-Sasanian provenance, demonstrates relatively early attempt to experiment with the combination of the "fixed" compositional formulae. At the same time the Kushano-Sasanian plates from Hermitage and Japanese private collection which represent rather firm compositional conventions, share with Mes 'Aynak plate numerous stylistic and iconographic features:

- The treatment of the robes between Hermitage plate (Fig. 22) and Mes 'Aynak (Fig. 1) is identical. The folds on the plate from Japanese collection (Fig. 14) are somehow less dense however they represent the same stylistic idea.

- All three represent identical elements of the horse-tack and mane coiffure - breast and hind straps being covered with the pattern of triangles which might be bells, all three horses have their manes trimmed and formed into large tuft of crest above the forehead with the ribbons on the temples. Naturally, the latter elements are not unique and the Hermitage plate (Fig. 22) horse has the mane trimmed in shape of crenellations while other two are straight, however, very often the horses in Sasanian iconography of combat with the beasts have different elements attached to the foreheads, often the crests/buns over the forehead and the temple ribbons are simply missing. They do not come in combination with the straps decorated in repetitive triangular motif. For example, Sari plate and stone disc show the same strap decoration but different horse coiffure (Fig. 16, 17). It is with mentioning that the horse coiffure from the Hermitage plate (Fig. 22) is very similar to the scenes of the king slaying lions from British Museum and Hermitage (Fig. 23). An analogy emphasised by the same hand position shown holding a sword and slashing beasts attacking diagonally upwards.

- The rapid and high raised front legs of the rearing horses from Hermitage plate (Fig. 22) and the plate from Japanese private collection
(Fig. 14) are rather unique stylistic feature in Sasanian iconography of combat with the beasts where the "flying gallop" is the predominant stylisation but in situations when the hind legs are shown on the ground and from ones raised, the angle is milder and the general impression far less dramatic.

- In all three pieces the heads of the horses are moved tightly back towards the necks. Such head position is not typical for Sasanian iconography of combat with the beasts. Very rounded necks of the horses are depicted in Sasanian triumphal and investiture rock reliefs but not in depictions of galloping or rearing horses. Also in monumental art of Sogdiana the horses are shown with their necks rounded, heads down, but with fair distance from the necks. Perhaps this represents superior dressage of the horses trained well for the optimal head position, while the depictions on Hermitage (Fig. 22), Japanese collection (Fig. 14) and Mes 'Aynak (Fig. 1) plates show horses terrified of the attacking beasts which possibly was to emphasise the heroism of the riders. This aspect seems to relate the depictions closer to the Escape-confrontation formula. If the latter was in fact a survival of the Central Asian Greek tradition, this association could be explained by geographical proximity, even if the differences in technique and workmanship are considerable.

Given the above, the relation between the three plates can be plausibly established, placing them in associated milieu, tradition or school. Additionally the similarity of the horse tack and entire formula adds to the closest analogies the depictions of the "lion hunt" from Hermitage (Fig. 22) and British Museum (Fig. 23), with Fabricius plate (Fig. 24) being seemingly the part of the same tradition but with very different technical treatment which might suggest chronological distance with the time when the technical skills were not trained or the scratched drawings were accepted as cheaper alternatives of former technologically advanced silver-smithery. This purely graphic quality relates the Fabricius plate (Fig. 24) even further towards the Chilek plate (Fig. 5) which represents the same convention of the sword held upright behind the torso. Again, the aspect of cheaper versions, excludes involvement of a court or state in production process. It is unlikely that the court officials of simply state officials would consider the cost of production of truly royal personages. 
The decoration of the plate from Mes 'Aynak proves that the approach to the scenes of "royal" or "princely" personages in Sasanian art was far more relaxed and diversified already in the Kushano-Sasanian oeuvre, this, in turn suggests that the differentiation in employment of the visual conventions was not suppressed by any governmental bodies. Even though the Berlin plate (Fig. 26) was suggested by Khurshudian to represent an Armenian school or tradition of Sasanian toreutics $^{72}$, one must agree that the differences in the corpus of available Sasanian toreutics do not allow attributing firmly particular features as specific geographic and/or chronological factors. The Kushano-Sasanian pieces are, in this case, unique as they point not only the geographical region but also the general period of their creation. Mes 'Aynak plate revolutionises the knowledge of the development and functioning of the Sasanian iconographic conventions, at the same time providing additional clues regarding possible geographic origin or evolution of the motifs. The pieces can be divided according to the stylistic and iconographic distance from discussed Mes 'Aynak plate:

- The group closest to Mes 'Aynak plate consists of the plate from Hermitage (Fig. 22) with the scene of boar fight and the plate from Japanese collection (Fig. 14). The similarities in treatment of the robes and of the horse tack and general composition were mentioned earlier. They are all undoubtedly related however the differences may represent different stages of evolution of Kushano-Sasanian art or simply different workshops of the East-Iranian school, absorbing the Sasanian influences while preserving the local post-Hellenistic features.

- The second group of relation consists of two, almost identical plates from Hermitage (Fig. 22) and British Museum (Fig. 23) and the scene from the "Hephtalite" bowl from British Museum (Fig. 11). The former two seem to perfectly fill the gap between Hermitage plate with "boar hunt" and Mes 'Aynak plate, containing the elements of both however the treatment of the garments, different way of depicting of the horse and differences in the horsetack make them the second closest. The bowl from British Museum is closer to Mes 'Aynak plate than any of the others but differs strongly

72 Khurshudian 2003: 272-286 in style and details. What attracts attention is that the royal personage on the British Museum bowl is fleeing a lion and a lioness which although turned to the opposite direction has her head directed towards the rider. This is far from the lion and the lioness attacking the rider on Mes 'Aynak piece but the relation is thus emphasised.

- The third group is made of Frabicius plate (Fig. 24) and the plate with Shapur killing a deer he is sitting on. The relation of the former comes from the position of the head of the horse which, although untypical for Sasanian art, was related to post-Hellenistic iconography of Bactria while the latter example corresponds by the body and arms position.

The above confirms that the Mes 'Aynak plate represents the eastern school of Sasanian or Kushano-Sasanian school toreutics. It also seems plausible that the employment of the swords in the scenes of the mounted combat with the beasts was initiated in this milieu which was probably less constrained with the fixed conventions than Central Iran or Mesopotamia. Application of the model of fighting the beasts with the sword of foot to the mounted formula was a first step, most likely followed by adoption of replacement of the thrust with slashing technique, at the same time allowing the elements of the local visual tradition to influence the borrowed Sasanian convention and re-design the conventions themselves.

\section{Literature}

Arnheim R. 1978. Sztuka i percepcja wzrokowa. Psychologia twórczego oka, Warszawa: Wydawnictwa Artystyczne i Filmowe.

Baulo A.V. 2002. Sasanidskoe serebranoe bludo $s$ r. Synya, Arheologiya i etnografiya Evrazii, Novosibirsk, 142-148.

Boardmann J. 2000. Persia and the West, London: Thames and Hudson.

Bollok A. 2015. The Visual Arts of the Sāsānian Empire and the Nagyszentmiklós/Sânnicolau Mare Treasure - A Non-Specialist's View. In: Daim F., Gschwantler K., Plattner G., Stadler P. (eds.), Der Goldschatz von Sânnicolau Mare (ungarisch: Nagyszentmiklós), Mainz: Romisch-Germanisches Zentralmuseum - Tagungen, 43-70. 
Ciafloni, Della Roca De Candal 2011. Sasanian Traditions in Sogdian Paintings: Hunting and Fighting Scenes, Parthica, Vol. 13, 111-128.

Compareti M. 2019. Assimilation and Adaptation of Foreign Elements in Late Sasanian Rock Reliefs at Taq-i Bustan. In: Asutay-Effenberger N., Daim F. (eds.), Sasanidische Spuren in der byzantinischen, kaukasischen und Islamischen Kunst und Kultur, Mainz: Schnell \& Steiner, 19-36.

Ettinghausen R. 1972. From Byzantium to Sasanian Iran and the Islamic World. Three Modes of Artistic Influence. Leiden: Brill.

Francfort H.P. 2002. Images du combat contre le sanglier en Asie centrale (3 ème au 1 er millénaire av. J.-C.), Bulletin of the Asia Institute vol. 16, 117-142.

Gaibov V.A., Košelenko G.A. 2008. A Horseman charging a Foot Soldier: A New Subject in Parthian Glyptic Art, Parthica 10, pp. 99-107.

Grabar O. 1967. Sasanian Silver. Late Antique and Early Mediaeval Arts of Luxury From Iran. Michigan: Ann Arbor.

Gray B. 1991. Post-Sasanian Metalwork, Bulletin of the Asia Institute Vol. 5. pp. 59-63.

Gunter A.C., Jett P. 1992. Ancient Iranian Metalwork in the Arthur M. Sackler Gallery and the Freer Gallery of Art, Washington D.C: Arthur M. Sackler Gallery and Freer Gallery of Art.

Harper P.O. 1978. The Royal Hunter. Art of the Sasanian Empire, New York: Asia Society.

Harper P.O. 1983. Sasanian Silver, in: E. Yarshater (ed.), Cambridge History of Iran 3 (2), Cambridge: Cambridge University Press, 1113-1130.

Harper P.O. 2000. Sasanian Silver Vessels: The Formation and Study of Early Museum Collections. In: Curtis J. (ed.), Mesopotamia and Iran in Parthian and Sasanian Periods: Rejection and Revival. C. 238 BC-AD 642. London: British Museum Press, 70-75.

Harper P.O. 2006. In Search of a Cultural Identity. Monuments and Artifacts of the Sasanian Near East. 3rd to 7th Century A. D., New York: Bibliotheca Persica, 10-11.

Harper P.O. 2008. Image and Identity: Art of the Early Sasanian Dynasty. In: V. S. Curtis, S. Stewart. L (eds.), The Sasanian Era. Vol. III. The Idea of Iran, London, New York: I.B. Tauris, 71-87.

Harper P. O., Meyers P. 1981. Silver Vessels of the Sasanian Period. Vol. I. Royal Imagery, New York: Metropolitan Museum of Art.

Herrman G. 2017. Ancient Ivory. Masterpieces of the Assyrian Empire, London: Thames and Hudson.
Khurshudian E. 2003. Armenia i sasanidskiy Iran (istoriko-kulturologicheskoe issledovanie), Almaty: Ministry of Foreign Affairs of the Republic of Armenia, The Embassy of the Republic of Armenia in the Republic of Kazakhstan and Kyrgyz Republic. National Academy of Sciences of the Republic of Armenia. Institute of Oriental Studies.

Mackintosh M.C. 1978. Taq-i Bustan and Byzantine Art: A Case for Early Byzantine Influence on the Reliefs of Taq-i Bustan, Iranica Antiqua Vol. 13, 149-177.

Marschak B.I. 1986. Silberschätze des Orients. Metalkunst des 3.-13. Jahr-hunderts und ihre Kontinuität. Leipzig: E. A. Seemann.

Maršak B.I. 1971, Sogdiyskoe serebro. Ocherki po vostochnoy torevtike, Moskva: Nauka.

Marshak B.I 2002. Pre-Islamic Painting of the Iranian Peoples and its Sources in Sculpture and Decorative Arts. In: E. Sims, B. I. Marshak, E. J. Grube (eds.). Peerless Images. Persian Painting and its Sources, New Haven, London:Yale University Press, 7-19.

Maršak B.I. 2017 Istoriya vostochnoy torevtiki IIIXIII vv. i problemy kulturnoy preemstvennosti, Sankt Petersburg: Academy of Culture's Research.

Maršak B.I., Kikiris Ya. B 1969 Chilekskie chashi, Trudy Gossudarsvennogo Ermitaža vol 10, 5580.

Mleziva J. 2016 Silver Vessels from Mes'Aynak. In: Stančo L. (ed.), Afghanistan. Rescued Treasures of Buddhism, Prague: Náprstek Museum, 99-105.

Moradi Y., Compareti M. 2019. A Sasanian figured relief plaque from Taq-e Bostan, Parthica 21, 179-188.

Pirson F. 2014. Ansichten des Krieges. Kampfreliefs klassischer und hellenistischer Zeit im Kulturvergleich, Wiesbaden: Dr Ludwig Reichert.

Preiser-Kapeller J. 2019. From one End of the (Post)Sasanian World to the other. Mobility and Migration between the Caucasus, Central Asia and the Persian Gulf in the 4th to 9th Century CE, In: Asutay-Effenberger N., Daim F. (eds.), Sasanidische Spuren in der byzantinischen, kaukasischen und Islamischen Kunst und Kultur, Mainz: Schnell \& Steiner, 9-18.

Reade J.E. 2018. The Assyrian Royal Hunt. In: Brerenton G. (ed.), The BP exhibition. Iam Ashurbanipal king of the world, king of Assyria. London: Thames and Hudson, 52-79.

Rosen-Ayalon M. 1991. A Non-Royal Hunter Vessel, Bulletin of the Asia Institute Vol. 5. 66-67. 
Ritter N.C. (2010), Die altorientalischen Traditionen der sasanidischen Glyptik. Form-Gebrauch-Ikonographie, Wien: LIT, Berlin.

Šlyahova V.I. 1977. Serebranyi sosud iz s. Yuldus (kurganskaya oblast), Sovetskaya Arkheologiya 1977/4, 288-292.

Skupniewicz P.N. 2009. Shafted Weapons of Sasanian Hunting Iconography, Fasciculi Archaeologiae Historicae Vol. XXII, 49-64.

Skupniewicz P.N. 2015. Tabriz Museum Battle Dish. Formal Considerations, Metamorfozy Istorii 6, Pskov, 180-211.

Skupniewicz P.N. 2018A. Mozaika Aleksandra Wielkiego i hellenistyczne ikony przemocy, Istorija Religiy Ukrainy Vol 28, 3-16.

Skupniewicz P.N. 2018B. Hellenistyczne estetyczne modele ujmowania walki konnej a Mozaika Aleksandra w kontekście eschatologicznym. Studium formalne. In: Minta-Tworzowska D. (ed.), Estetyka $w$ archeologii. Obrazowanie w pradziejach i starożytności, Gdańsk: Polska Akademia Nauk, Muzeum Archeologiczne w Gdańsku, 317-342.
Skupniewicz P.N. 2019 'Sasanian'silver plate from al-Sabāh Collection in light of aesthetic features of Sasanian toreutics, Historia i Świat Vol. 8, 59-78.

Soudavar A. (2003), The Aura of Kings: Legitimacy and Divine Sanction in Iranian Kingship, Costa Mesa: Mazda Publishers.

Swietochowski M.L., Carboni S. 1994, Illustrated Poetry and Epic Images. Persian Painting of the 1330s and 1340s, New York: Metropolitan Museum Press.

Tanabe K. 2001. A Kushano-Sasanian Silver Plate and Central Asian Tigers, Silk Road Art and Archaeology Vol. 7, 167-186.

Thompson E. 2008. Composition and Continuity in Sasanian Rock Reliefs, Iranica Antiqua Vol. 43, 300-358.

Trever K. V., Lukonin V. G. 1987. Sasanidskoe serebro. Sobranie Gosudarstvennogo Ermitaža. Hudožestvennaya kultura Irana III-VIII vekov. Moskva: Iskusstvo.

Patryk Skupniewicz ORCID 0000-0002-8119-5449

University of Natural Sciences and Humanities in Siedlce, Poland Institute of History patryk.skupniewicz@gmail.com

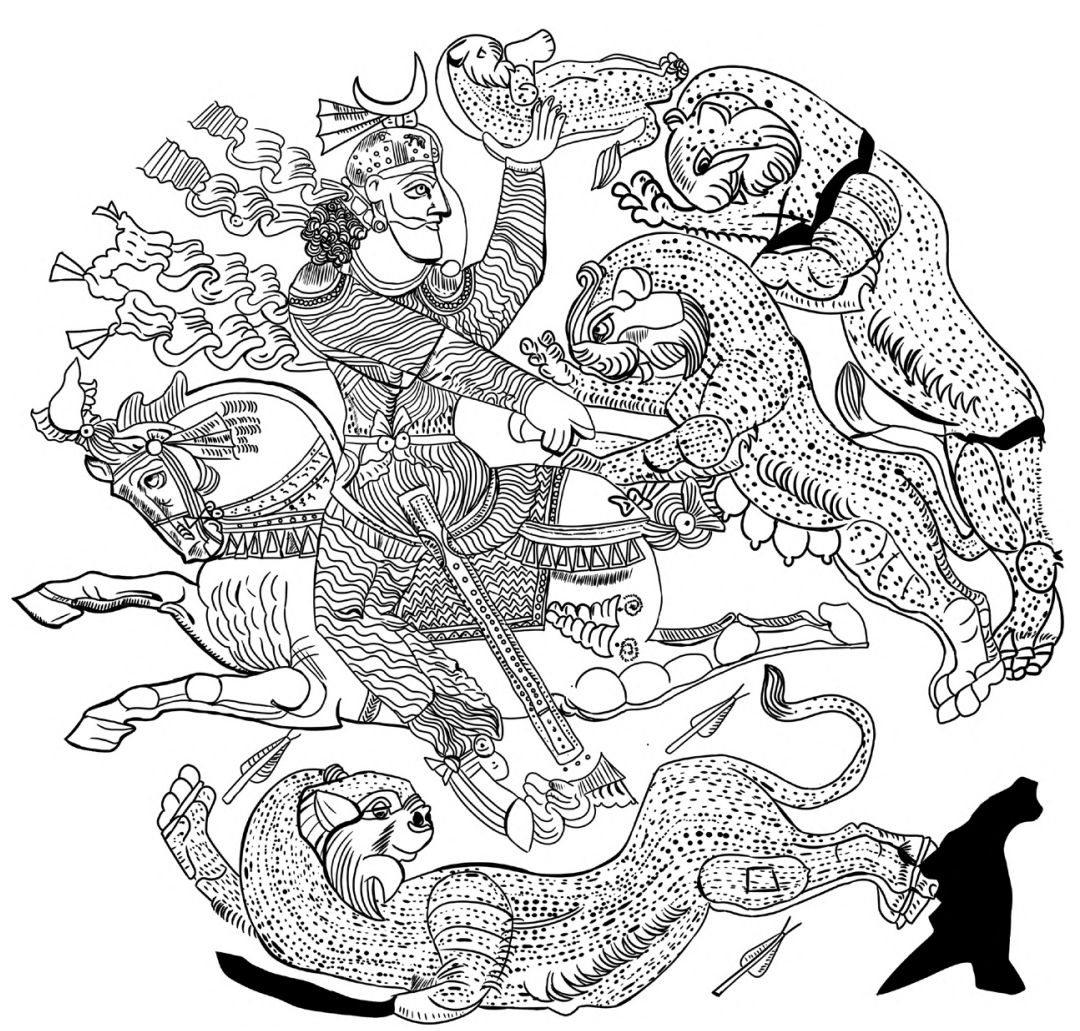

Fig. 1. Scene from the Mes 'Aynak silver plate 


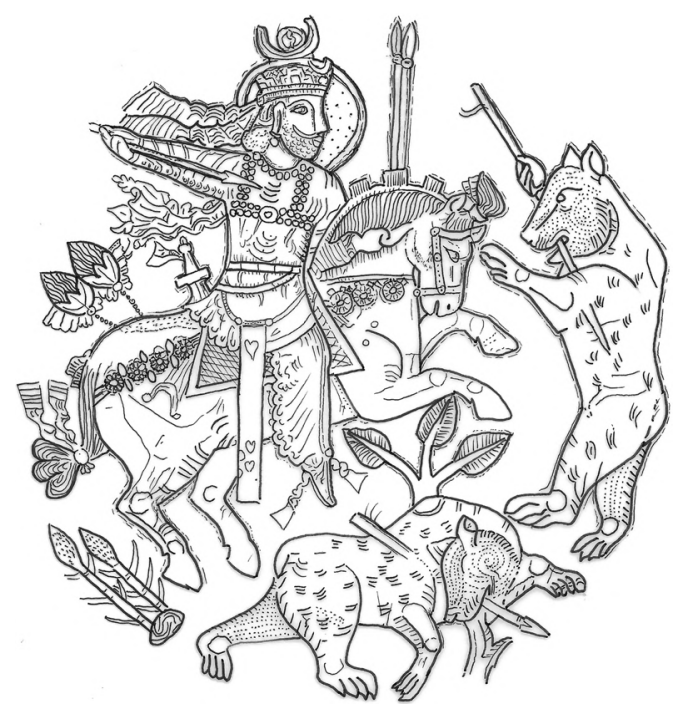

Fig. 2. Scene from the plate from Anikovska, Pushkin Museum

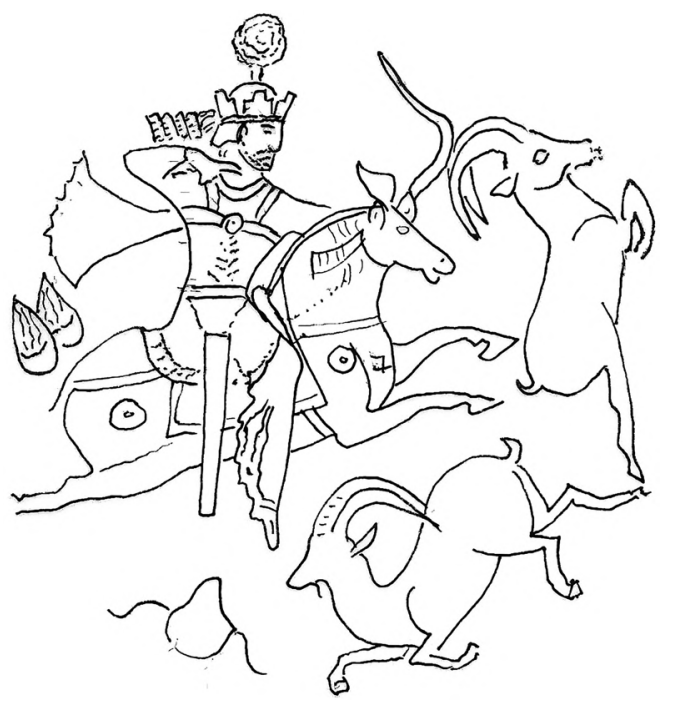

Fig. 4. Scene from the Arthur Sackler Gallery plate, S1987.109

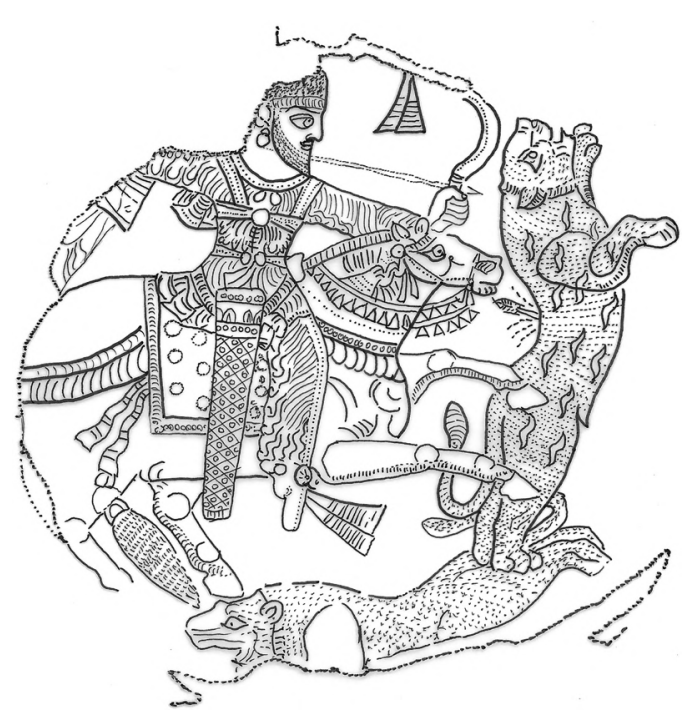

Fig. 6. Scene from the plate from Kutais in Hermitage, S 58

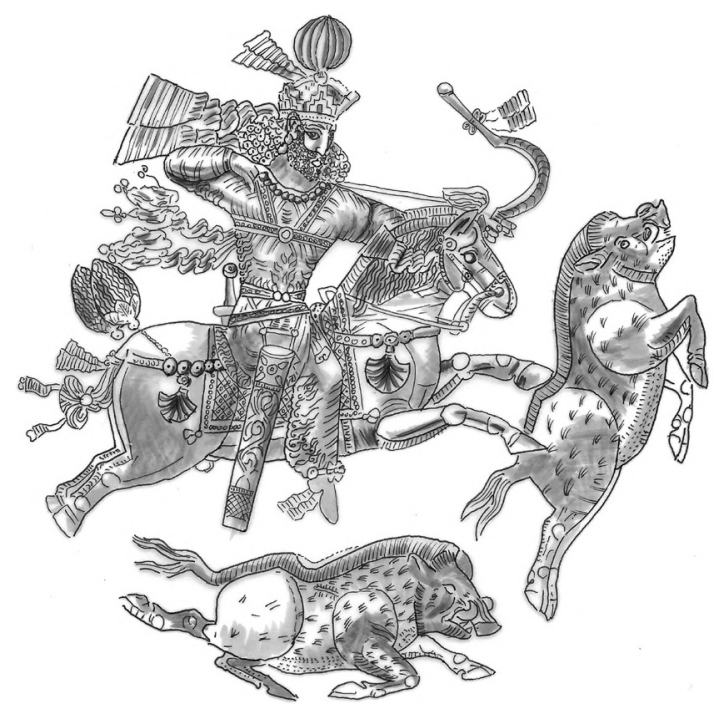

Fig. 3. Scene from the plate from Feer Gallery of Art

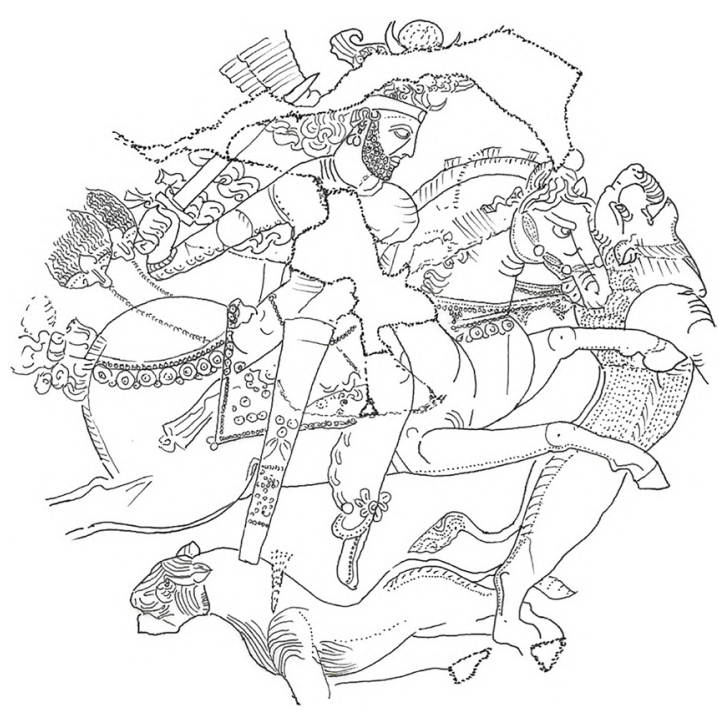

Fig. 5. Scene from plate from Chilek

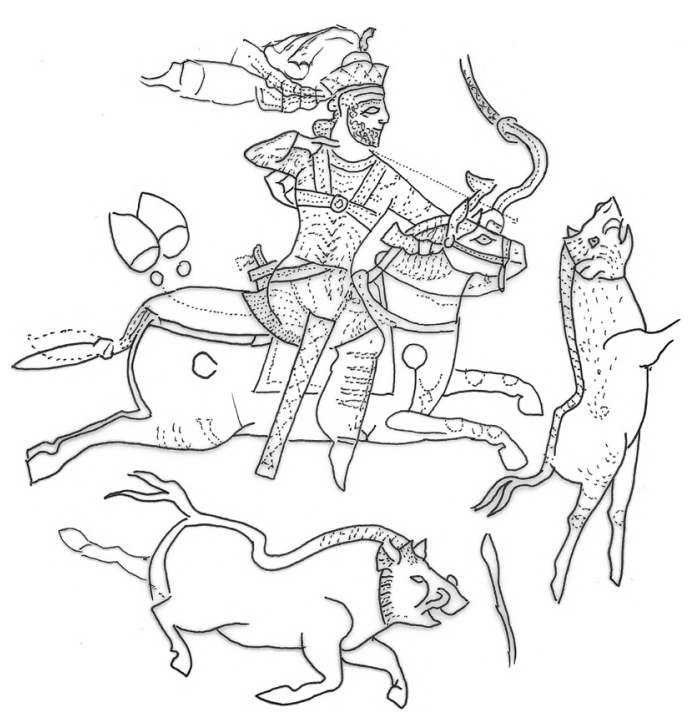

Fig. 7. Scene from the plate plate from Nizhne Shakhrovka 


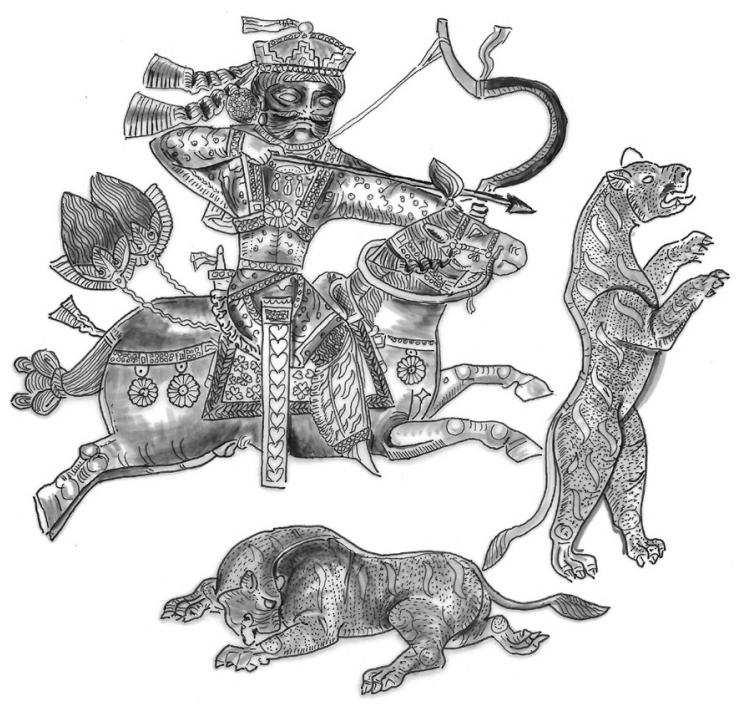

Fig. 8. Scene from the plate post-Sasanian plate from Hermitage, S-13

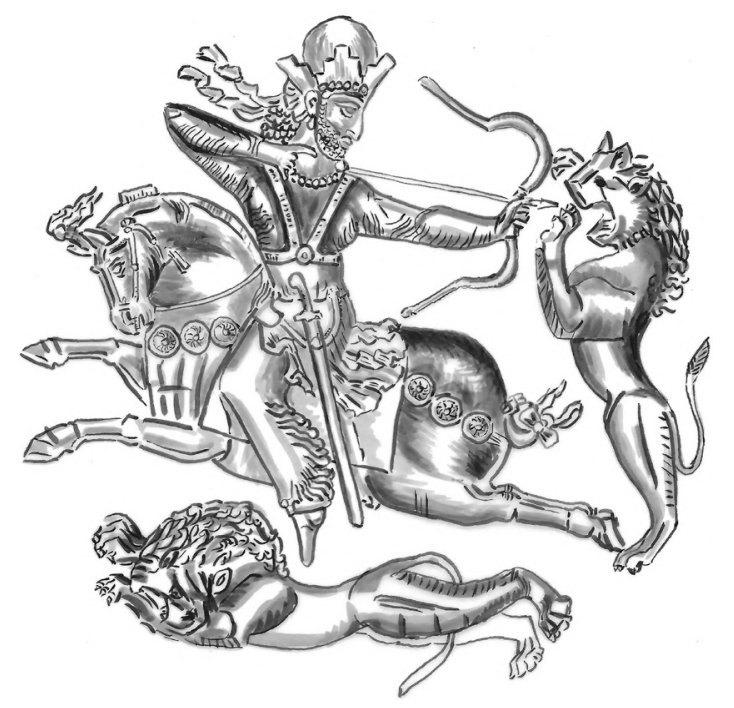

Fig. 10. Hermitage plate with Shapur, S-253 (Trever, Lukonin 1987, 107, Pl. 10)

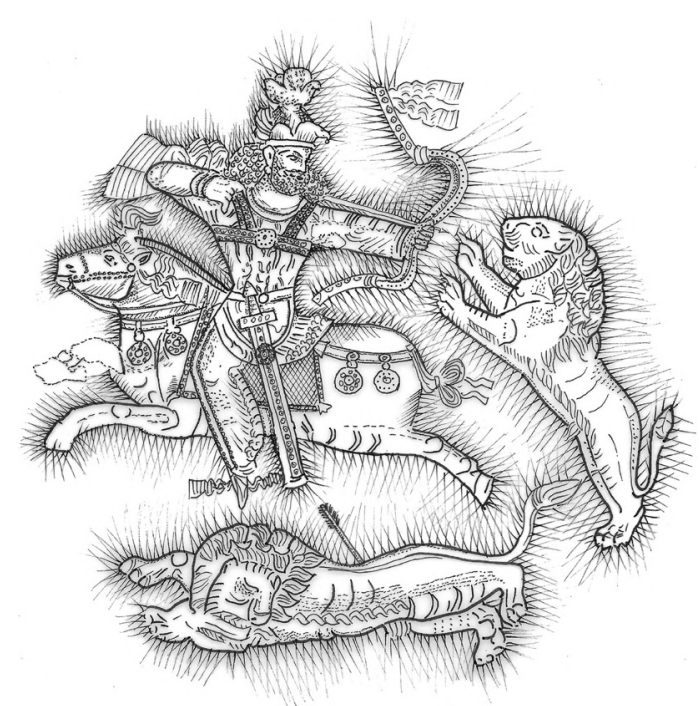

Fig. 9. Scene from the Cleveland Museum of Art plate, 62.150

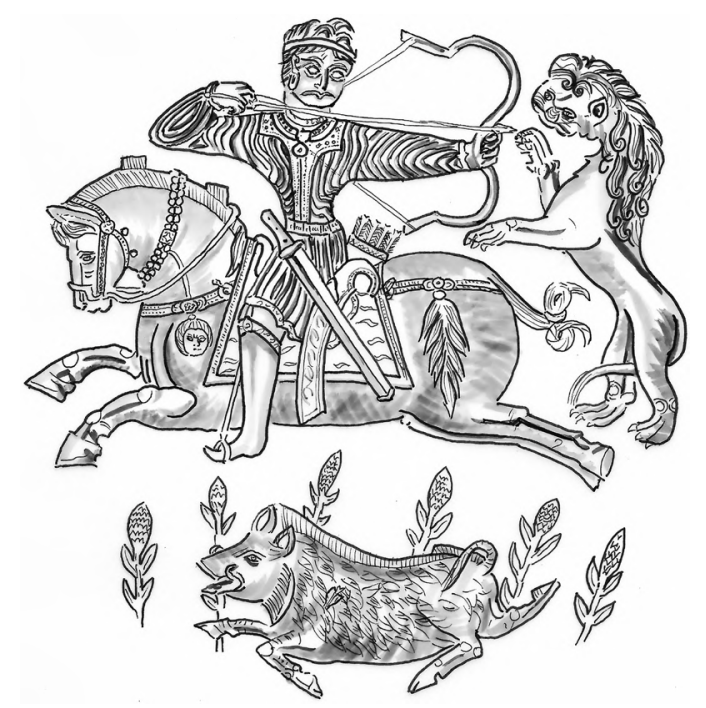

Fig. 11. Scene from the the Pur-e Vahman plate in Hermitage, S-247
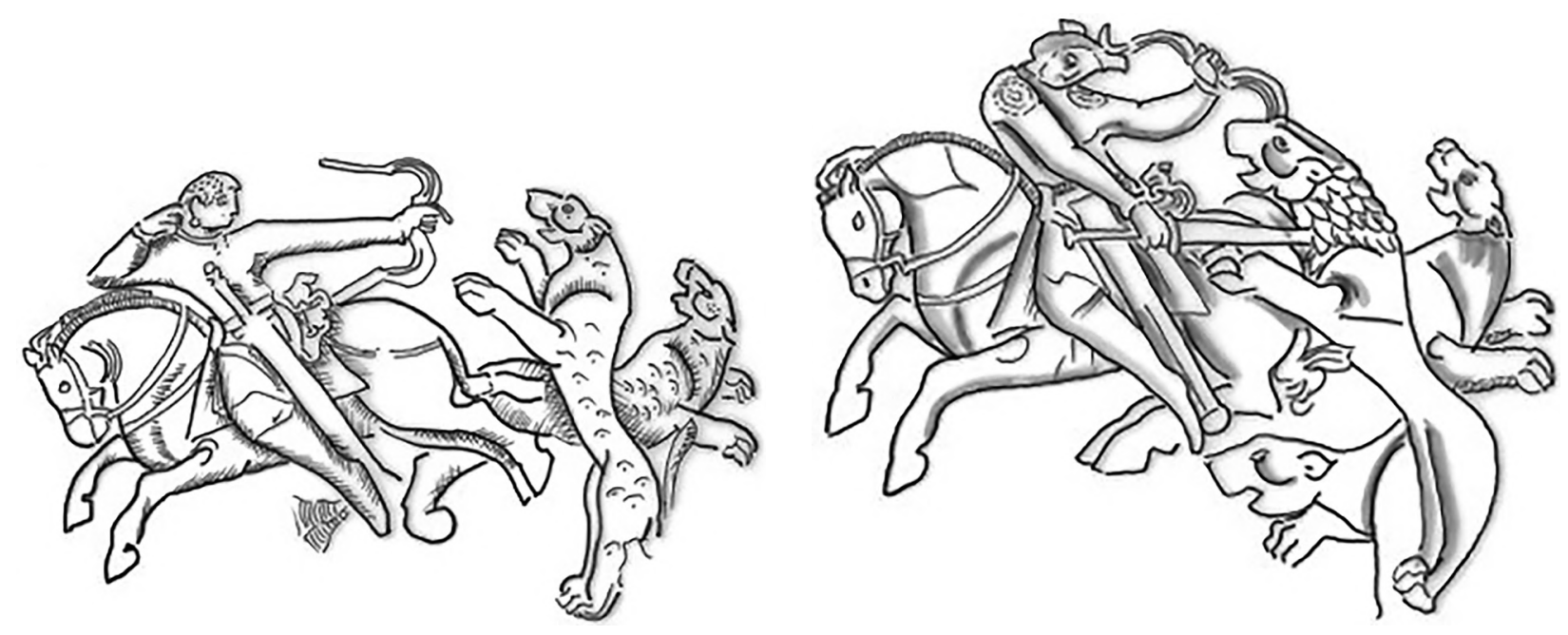

Fig. 12. Scene from the bowl identified as Hephtalite from British Museum, OA 1963-12-10.1 


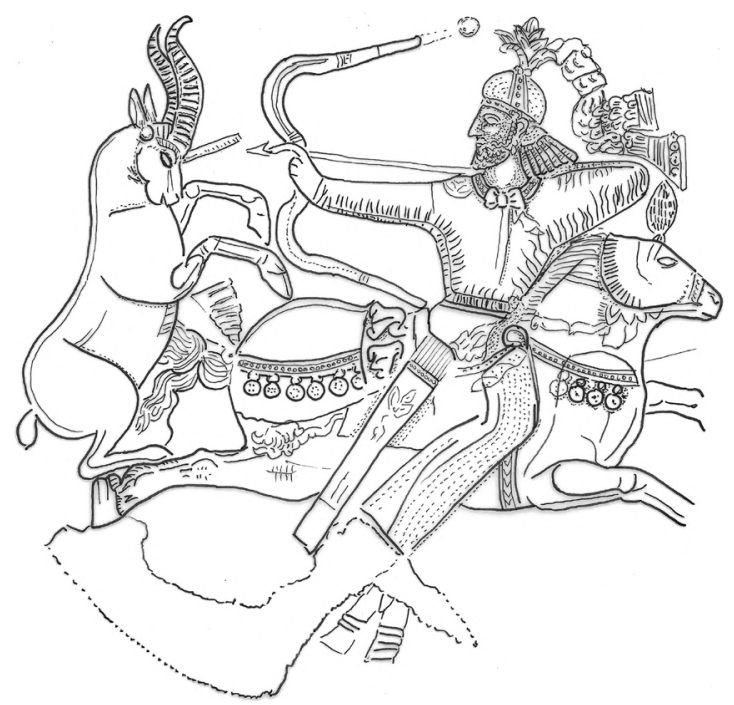

Fig. 13. Scene from the Shemakha plate

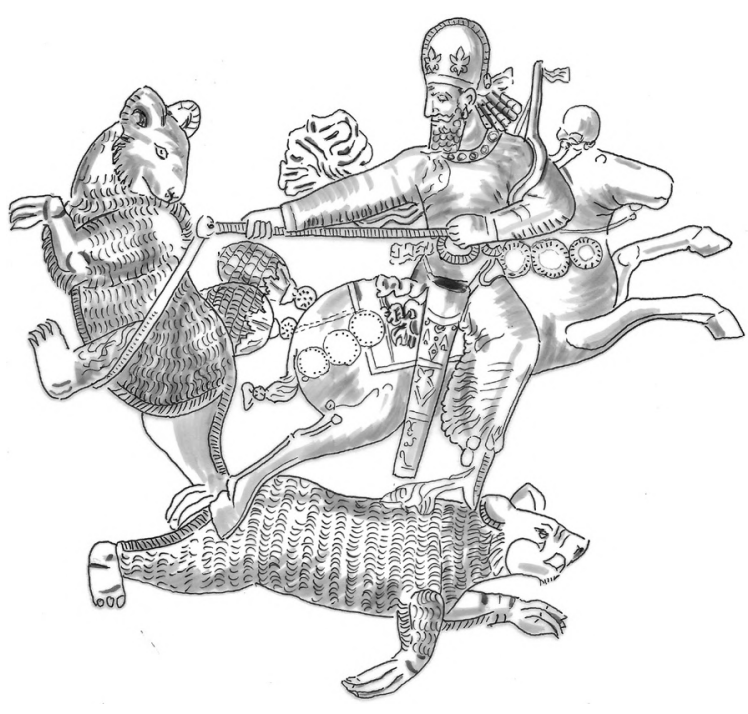

Fig. 15. Scene from the Krasnaya Polyana plate in Abkhazian State Museum, 47-71

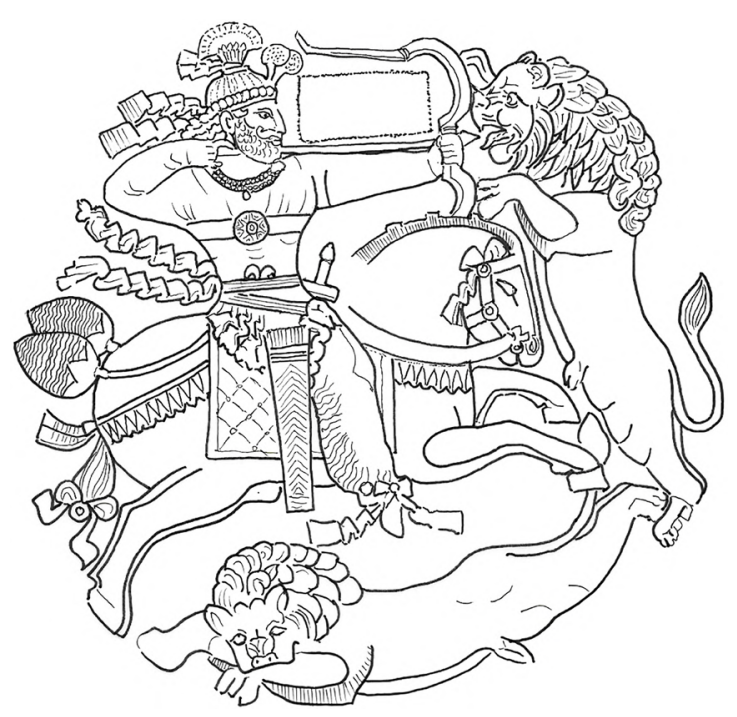

Fig. 17. Depiction on the stone disc from Sari

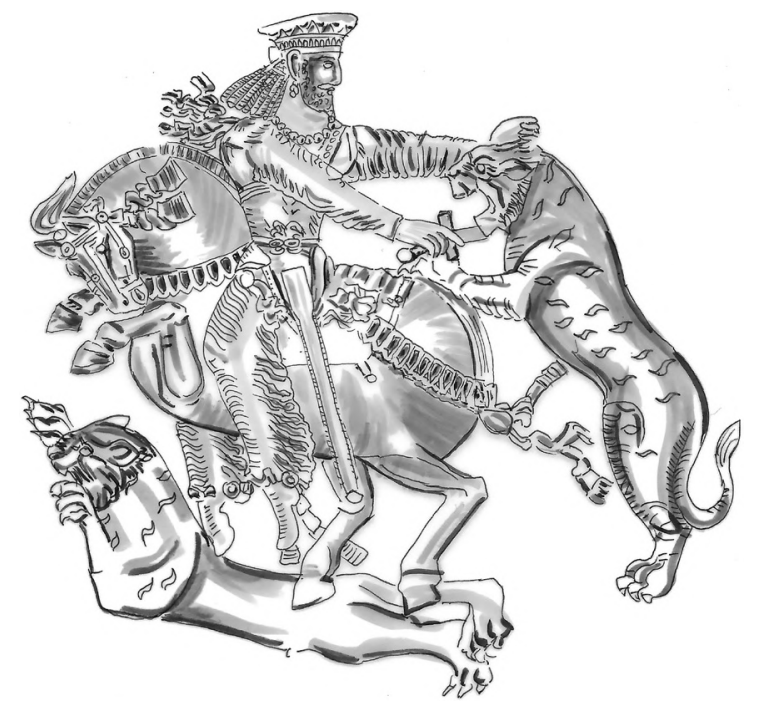

Fig. 14. Scene from the Kushano-Sasanian plate from private, Japanese collection

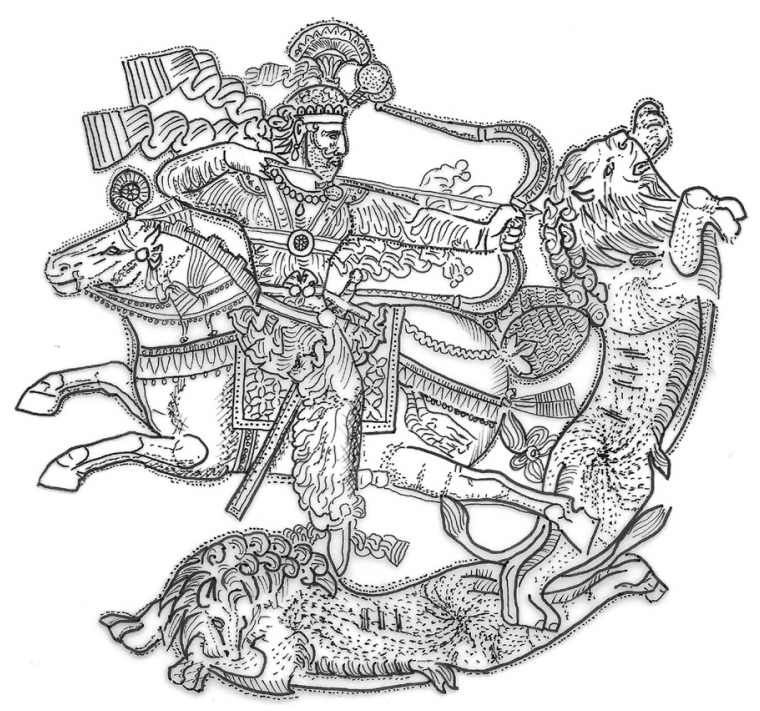

Fig. 16. Scene from the Sari plate in Iran Bastan Museum, 1275

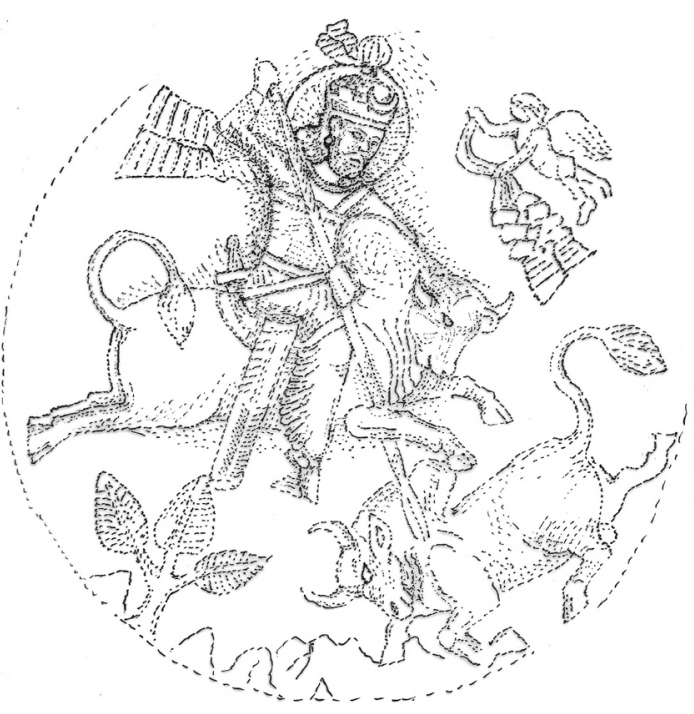

Fig. 18. Scene on the Synya family plate 


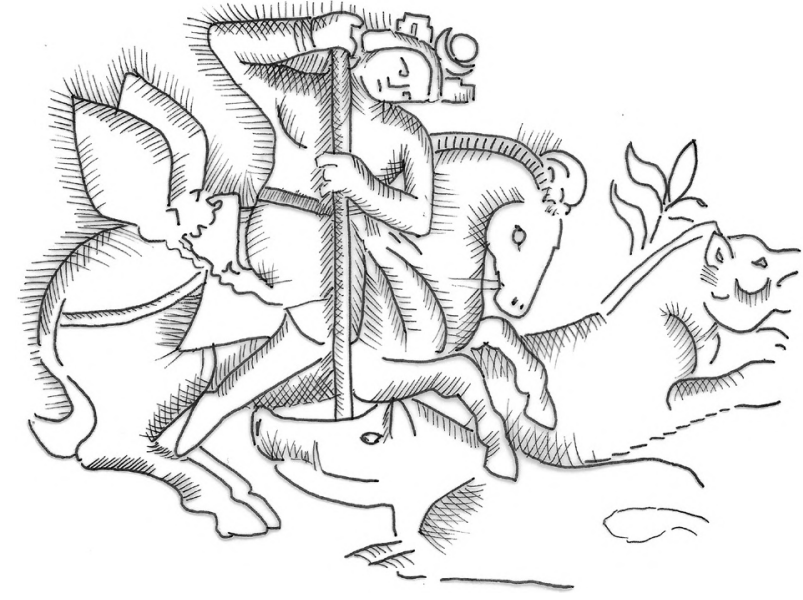

Fig. 19. Scene on the bowl identified as Hephtalite from British Museum, OA 1963-12-10.1

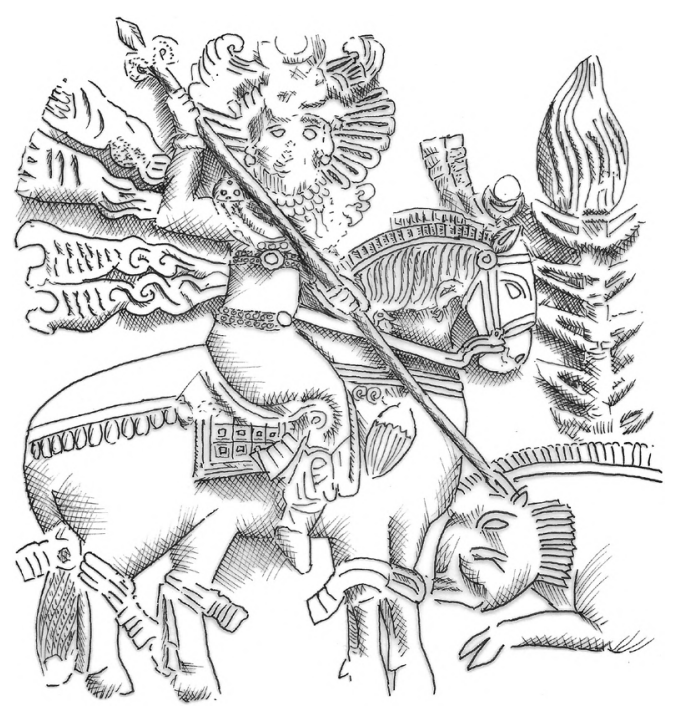

Fig. 20. Depiction on the stucco reliefs from Chal Tarkhan
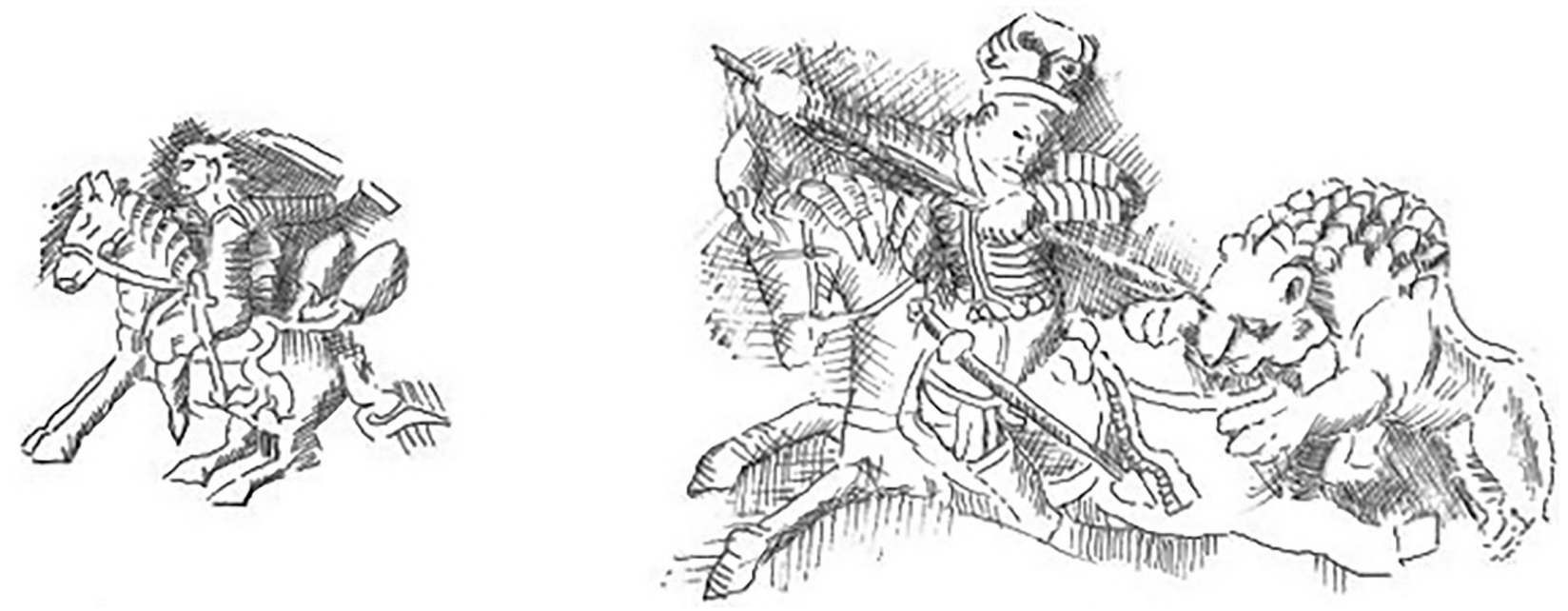

Fig. 21. Depiction

on the vase from Yuldus

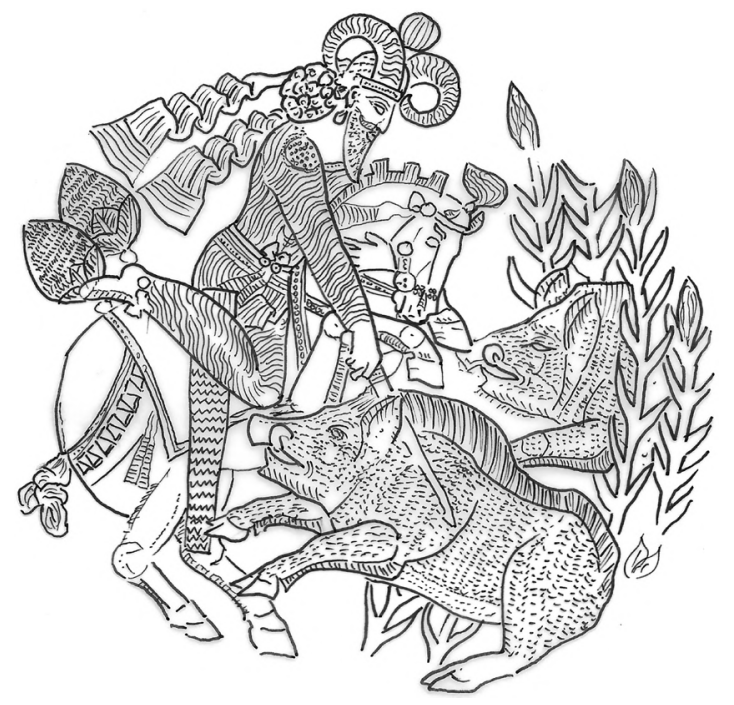

Fig. 22. Depiction of Kushanshah Bahram on the plate from Hermitage, S24

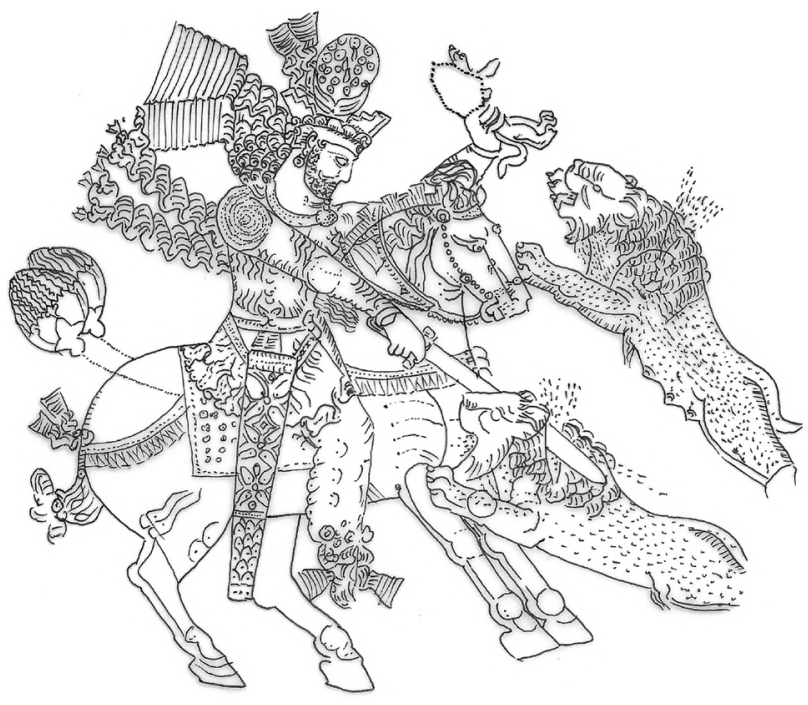

Fig. 23. Two, almost identical scenes with a king combating the tigers from British Museum (124092) and Hermitage 


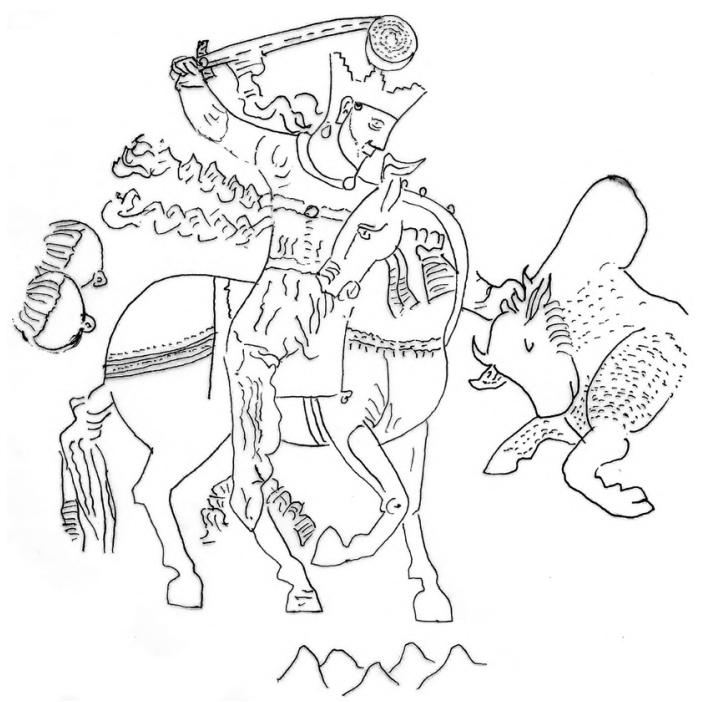

Fig. 24. Scene from Fabricius collection plate

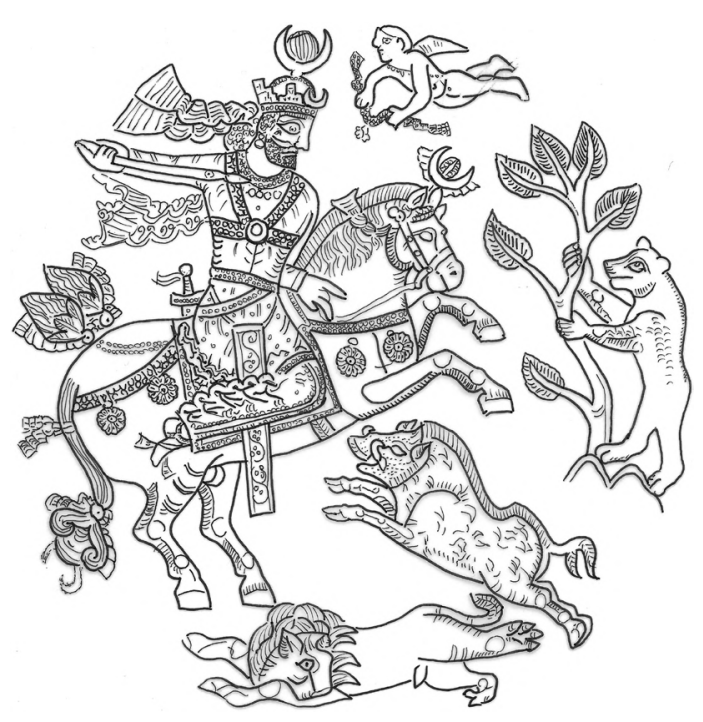

Fig. 26. Scene on the plate from Museum fur Islamische Kunst, Berlin, I.4925

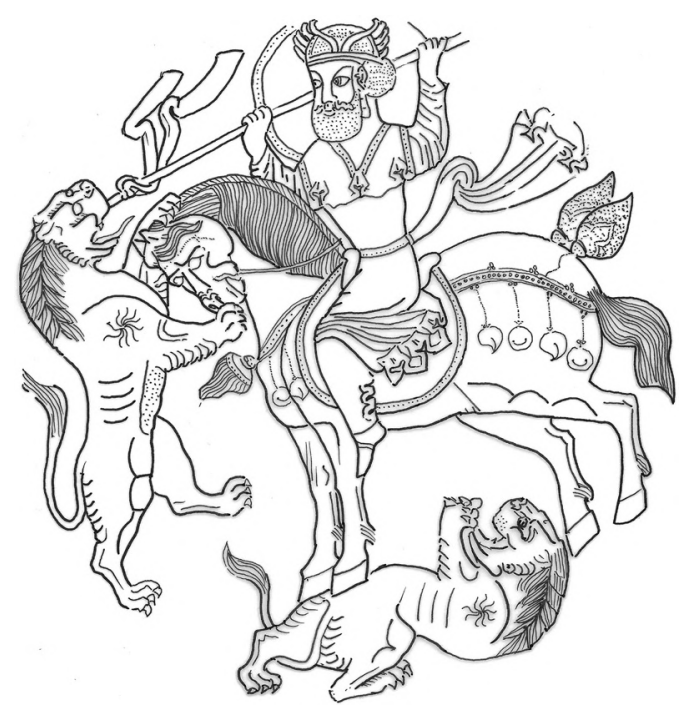

Fig. 28. Sogdian imitation of Sasanian plate with the lion-hunt

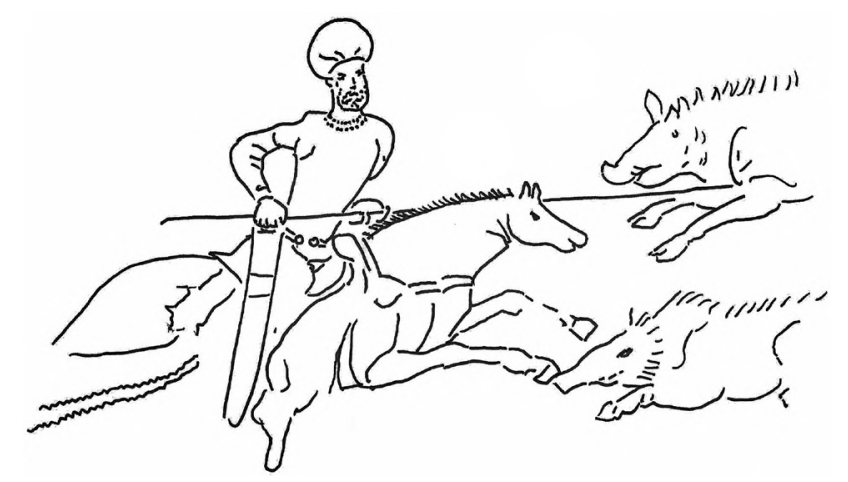

Fig. 25. Depiction on the late Parthian graffiti from Hatra

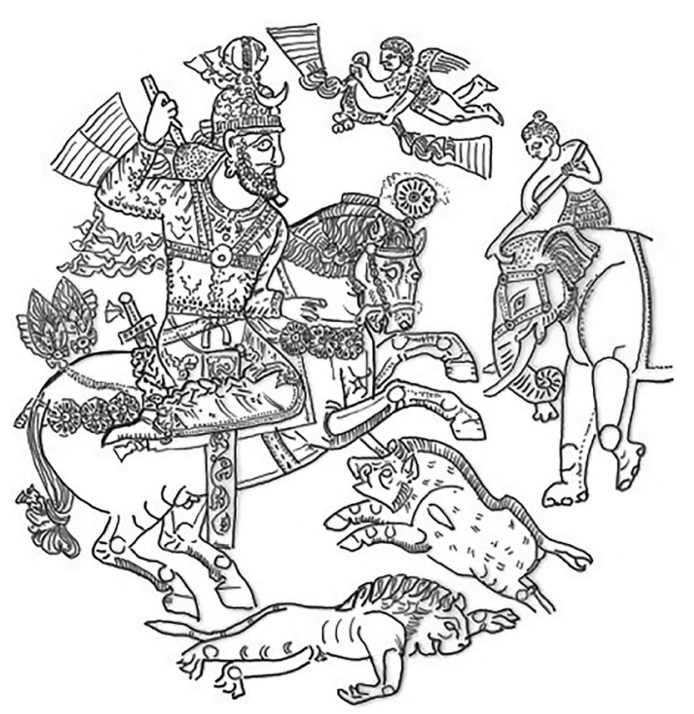

Fig. 27. Scene on the Bastis collection plate

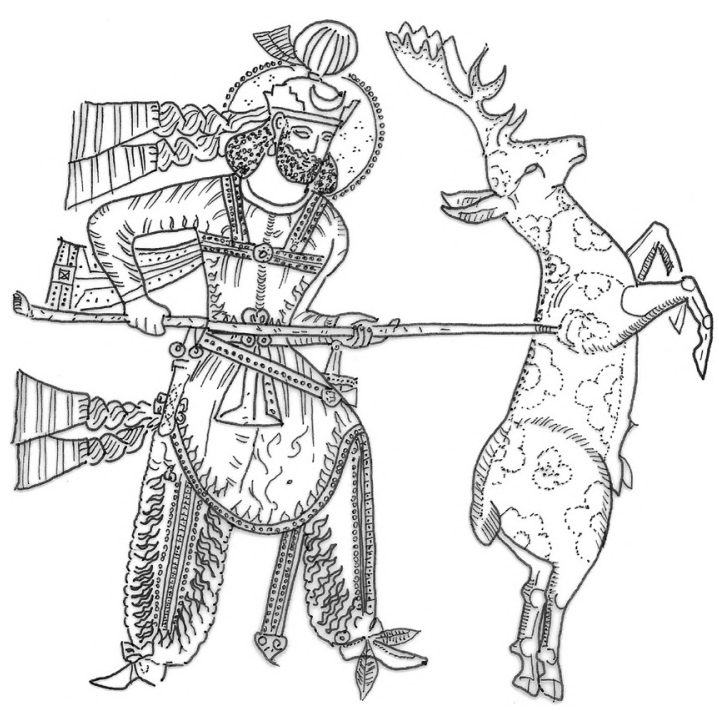

Fig. 29. Scene from the plate with Yazdegird I killing a deer, Metropolitan Museum of Art, 1970.6 


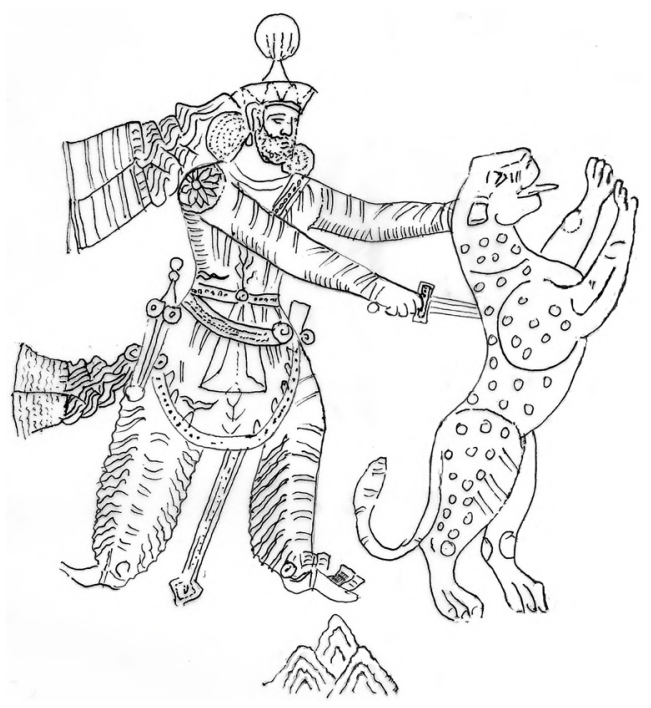

Fig. 30. Scene from the Klimova plate from the Hermitage, S42

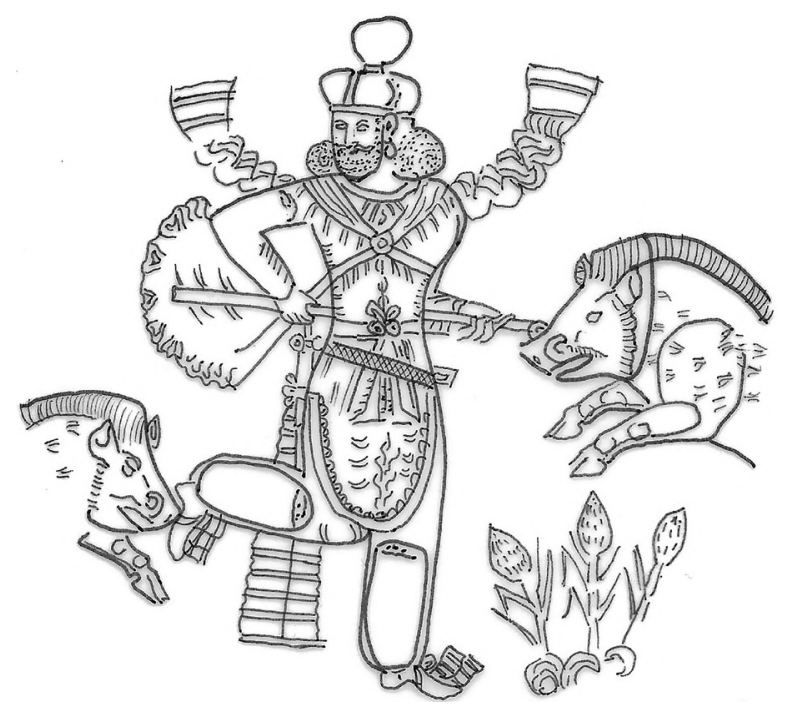

Fig. 32. Shelby and White Collection plate

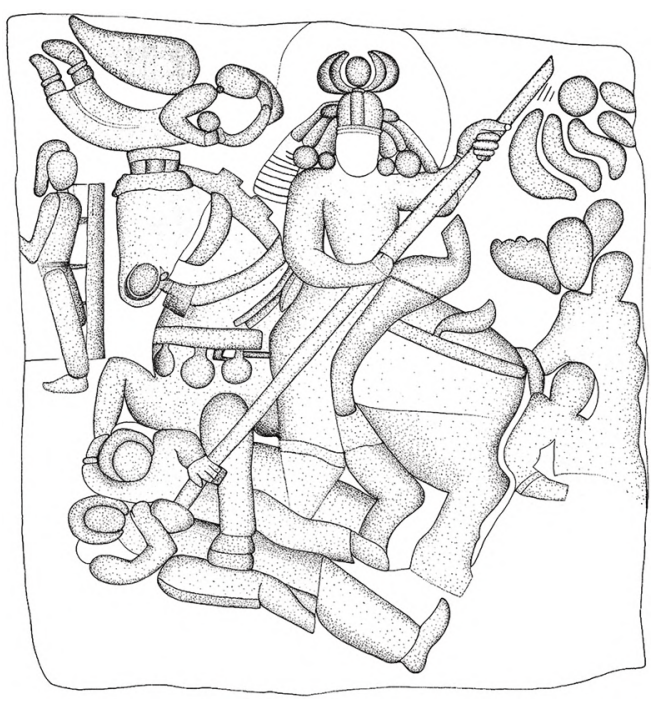

Fig. 34. Depiction on the stone relief found in Taq-e Bostan

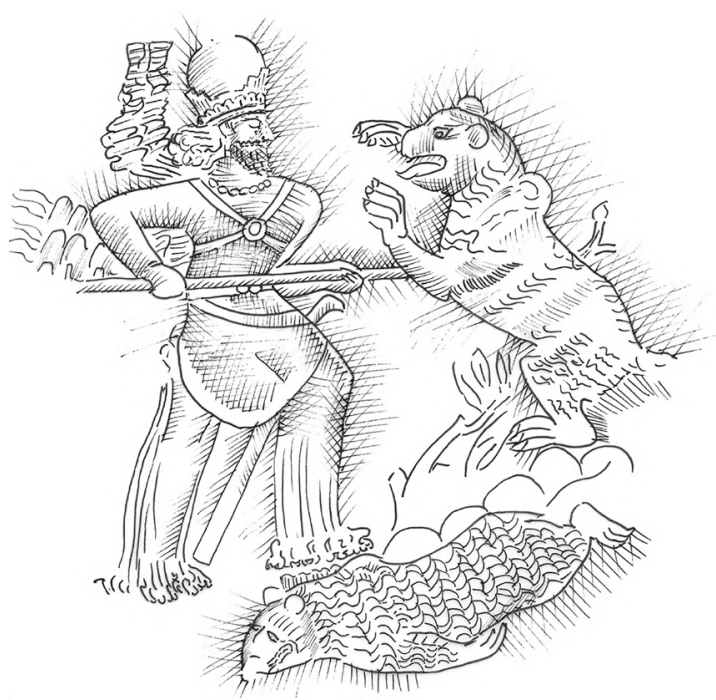

Fig. 31. Scene from the Plate from Shogakukan collection

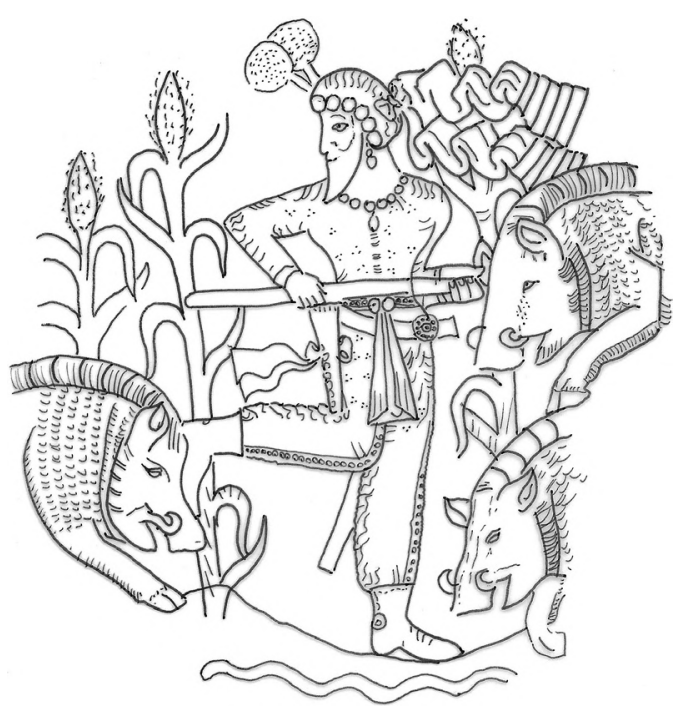

Fig. 33. Plate from the Tomb of Feng Hetu

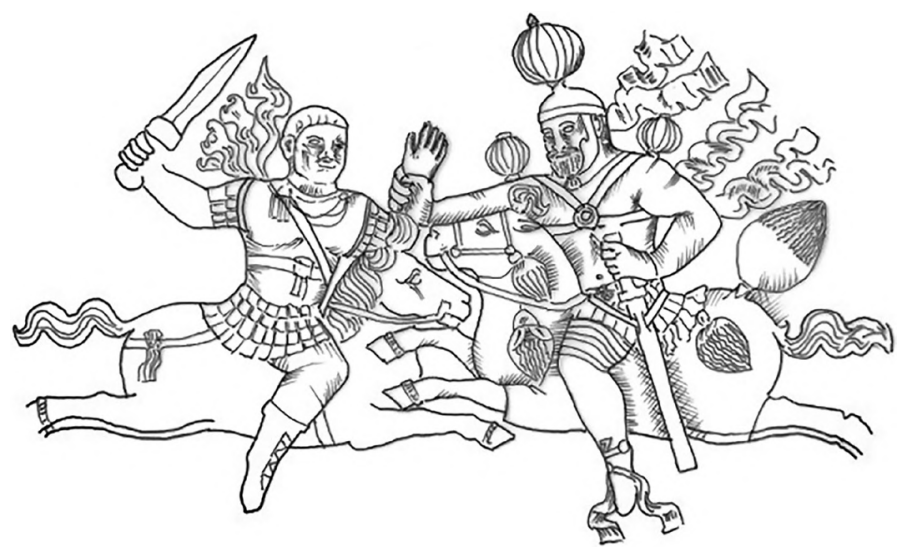

Fig. 35. Shapur cameo 